\title{
Offshore port service concepts: classification and economic feasibility
}

\author{
Jonghoe Kim • James R. Morrison
}

Received: 16 January 2011/Accepted: 19 May 2011/Published online: 12 June 2011

(C) The Author(s) 2011. This article is published with open access at Springerlink.com

\begin{abstract}
Most prevalent among the approaches to address the ever increasing demands for port capacity are the construction of new berths, installation of faster cranes and optimization of existing resources. A less common approach is to employ offshore port service concepts. Here, we endeavor to provide a complete survey of such nontraditional offshore service concepts and demonstrate that all, except a few very unusual concepts, can be well classified into one of thirty two structures or their combinations. Advantages, disadvantages and the container handling chain are discussed. We identify which of these structures can provide any of six possible operational modes. We next focus on a subset of the thirty two structures called the mobile harbor. This concept has recently been proposed and shares some similarities with midstream operation in Hong Kong. We endeavor to address the fundamental question: "Should such a concept be implemented?" We develop an estimate of the cost per unit threshold below which this concept will be viable. The per unit cost estimate of current $\mathrm{MH}$ designs is within about $6 \%$ of the economic viability threshold for traditional operation in Hong Kong. Other operational modes are not as favorable. As our focus is on the feasibility of the operational paradigm, we do not here address technology issues except to note ongoing efforts to resolve technology hurdles.
\end{abstract}

Keywords Container transport · Midstream operations - Mobile harbor . Economic analysis

\footnotetext{
J. Kim · J. R. Morrison ( $₫)$

Department of Industrial and Systems Engineering, KAIST, 291 Daehak-ro, Yuseong-gu, Daejeon 305-701, South Korea e-mail: james.morrison@kaist.edu

URL: http://xS3D.kaist.edu

J. Kim

e-mail: windf@kaist.ac.kr

URL: http://xS3D.kaist.edu
} 


\section{Introduction}

Historically, demand for container transport services has increased steadily (Drewry 2007a). Coupled with and driven by the increasing container transport volumes is an increase in the size of containerships (Drewry 2007b). However, ships with capacities in excess of 6,500 TEU (20 foot equivalent unit container) require deep water berths; only about 5\% of existing ports can serve them (Baird and Jeon 1999). To increase container port capacity and capabilities, it is traditional to build more berths, construct or upgrade to faster equipment and optimize port operations. Berth construction is very expensive and requires both a sufficient length of sea shore and land adjacent to the shore for yard operations. Improved harbor equipment may include double sided unloading capability, faster cranes (e.g., tandem lift) and automated mooring (Cavotec 2011). The literature teems with descriptions of efforts ranging from optimization (Huang et al. 2009; Liang et al. 2009; Vis and Carlo 2010) to efficiency studies (e.g., data envelopment analysis (Tongzon 2001)). It is important to note that when increasing berth capacity by any means, a corresponding increase in yard capability is also required.

As an alternative to these approaches, we focus on non-traditional offshore container port service concepts. The paper first

- Develops a logical categorization of offshore port services,

- Identifies six operational modes for offshore port service,

- To our knowledge, provides the first complete survey of offshore port service concepts, and

- Discusses advantages, disadvantages and the container handling chain.

We have a particular interest in a recently proposed offshore system called the mobile harbor (MH) (Suh 2008). Offshore (un)loading systems, or midstream operations, have been in use for many years at ports such as Hong Kong (Fung 2001). However, such systems are not as safe nor efficient as container unloading at a traditional berth. The $\mathrm{MH}$ attempts to resolve the weaknesses of existing midstream operations. We focus our attention on the fundamental question: "Should such a concept be implemented?" Employing industry standard techniques and actual industry cost data, we develop an estimate of the cost threshold for economic feasibility of the $\mathrm{MH}$ concept. We study the economic viability of the $\mathrm{MH}$ for the six operational modes, and conduct detailed sensitivity analysis on key cost/ operational parameters.

The remainder of the paper is organized as follows. A logical categorization of offshore port services and operational modes is provided in Sect. 2. In Sect. 3, we provide a survey of existing offshore operation concepts. In Sect. 4, we discuss data collection and preparation. Industry standard analysis to compare the MH offshore concept with traditional port designs is conducted in Sect. 5. We provide concluding remarks in Sect. 6.

Note the following. Some the results presented in this paper have appeared in a brief conference version (Morrison and Lee 2009). We use the word "offshore" to indicate floating or positioned primarily over water. Our focus is exclusively on container transport and not bulk cargo. 


\section{Classification of offshore operation concepts}

Here we provide a classification for the numerous offshore service concepts and structures that have been implemented and proposed. To our knowledge, it is exhaustive in the sense that all concepts mentioned in the literature are readily included. We discuss operational modes for each.

\subsection{Classification of offshore structures}

We first develop a classification for offshore structures that is defined by the five binary variables $B, C, L, M$ and $R$. Each binary variable will serve as an indicator for whether a floating structure possesses a particular feature. For example, $B=1$ will indicate that the floating structure has a buffer for the storing of containers. Otherwise, if $B=0$, the floating structure does not possess a buffer. These binary variables are provided in Table 1.

The acronym RORO is used to describe a structure that (un)loads cargo via a rollon/roll-off system. RORO ships have been used to transport cars which are driven on and off the ship. We use the binary variable $R$ to indicate whether an offshore structure has RORO capability for containers or not. It does not necessarily imply that two RORO capable structures can interface with each other. For example, two RORO feeder ships will not normally be able to transfer containers from one to the other. However, a RORO capable offshore port will be prepared to accept from and deliver containers to a RORO feeder ship. The $R$ variable simply implies that there is some RORO capability for containers. More detail is required to assess interface capabilities.

One could readily extend the binary variables to allow finer distinction. For example, the variable $B$ could allow multiple values, each corresponding to a range of container buffer sizes. The variable $M$ could indicate varying degrees of mobility. Also, the variable $B$ could allow for other types of cargo such as bulk cargo

Table 1 Interpretation of the binary variables $B, C, L, M$ and $R$ for an offshore structure

\begin{tabular}{lll}
\hline Variable & Value & Interpretation \\
\hline$B$ & 0 & No container buffer present \\
$B$ & 1 & Container buffer present \\
$C$ & 0 & No container cranes onboard \\
$C$ & 1 & Container crane(s) onboard \\
$L$ & 0 & There is no fixed link to land \\
$L$ & 1 & Structure has a permanent immobile physical link to the land (e.g., bridge or directly \\
& & affixed to land) \\
$M$ & 0 & Structure is not intended/capable of being moved more than once per day (relatively \\
& & immobile) \\
$M$ & 1 & Structure is intended for or capable of frequent movement (more than once per day) \\
$R$ & 0 & Structure has no container roll-on/roll-off (RORO) capability \\
$R$ & 1 & Structure has some container RORO capability \\
\hline
\end{tabular}


(e.g., coal, steel) or even other ships! Other extensions could be included via additional variables. However, the five binary variables given are sufficient to describe all existing offshore container concepts except one. Modifications may allow the classification of land-based container ports.

We use the tuple $(B, C, L, M, R)$ to describe features of floating structures. Table 2 lists the thirty two possible combinations of the binary variables. There, $S \#$ indicates the number we are associating with the structure; e.g., floating structure $S 0$ has the features corresponding to the tuple $(0,0,0,0,0)$. The "Feasible" column provides a "Y" or " $\mathrm{N}$ " to indicate whether the resulting features can logically occur on a single floating structure that is used for container porting services. We consider a structure as infeasible if both $L=1$ and $M=1$, since a mobile structure cannot possess an immobile physical connection to the land. Also, structures 0,2 and 4 have no capability to provide container transport service. The column "References" provides references for the concept; we discuss each in the sequel.

By combining the structures in Table 2, offshore components of concepts from the literature can be constructed. Table 3 provides these combinations.

In addition to classifying the components of existing concepts, new concepts have arisen. For example, $S 21$ is an offshore floating structure with a container buffer, physical connection to land and RORO capability. Assuming it can provide service to RORO vessels, it is thus an offshore RORO port with land connection.

\subsection{Operational modes for offshore port service}

The feasible structures of Table 2 may provide the following operation modes:

- Transport containers (as in a feeder ship) (Suh 2008; Yang 2009; Yang et al. 2009b; Wright 2010),

- Replace a traditional port (three cases) (Suh 2008; Yang 2003; Yang 2009; Yang 2009; Yang et al. 2009b; HKMOA 2009),

- Transfer containers from ship to ship (Abdel-Maksoud and Wichner 2008; Gottwald 2010; Han and Kim 2009; Han et al. 2009; Morrison et al. 2009a; Suh 2008; Yang 2009; Yang et al. 2009b), and

- Supplement container (un)loading at a traditional port (Chae at el. 2007; Gottwald 2010; March 2005; Suh 2008; Yang 2009; Yang et al. 2009b).

The structure's tuple enables us to identify which operational modes it may offer. Table 4 gives conditions on the tuple to allow an operational mode. As shown, we term these modes M1 ,.., M6; see Table 4. There are three possibilities. If the condition listed in Table 4 is not met, then that operational mode is not possible for the structure; we mark it with an "N". If the condition is met, there are two possibilities. Either, the operational mode is possible with no modifications to the structure of existing container ships ("Y"). Or, the operational mode is possible if the containerships served are able to (un)load cargo to a RORO capable offshore structure ( " $\gamma$ "). For example, $S 8$ can be used as a supplementary resource in a traditional port because it has $C=1 . S 3$ may be used as a supplementary resource for RORO capable ships (" $\gamma$ ") since it has RORO capability and no crane $(R=1$, $C=0)$. 
Table 2 Feasibility of floating structures and references

\begin{tabular}{|c|c|c|c|}
\hline$S \#$ & $(B, C, L, M, R)$ & Feasible & References \\
\hline SO & $(0,0,0,0,0)$ & $\mathrm{N}$ & \\
\hline$S 1$ & $(0,0,0,0,1)$ & Y & Static RORO interface of [1] \\
\hline$S 2$ & $(0,0,0,1,0)$ & $\mathrm{N}$ & \\
\hline$S 3$ & $(0,0,0,1,1)$ & Y & Mobile RORO interface of [1] \\
\hline$S 4$ & $(0,0,1,0,0)$ & $\mathrm{N}$ & \\
\hline$S 5$ & $(0,0,1,0,1)$ & $\mathrm{Y}$ & \\
\hline$S 6$ & $(0,0,1,1,0)$ & $\mathrm{N}$ & \\
\hline$S 7$ & $(0,0,1,1,1)$ & $\mathrm{N}$ & \\
\hline$S 8$ & $(0,1,0,0,0)$ & $\mathrm{Y}$ & $\begin{array}{l}\text { Crane unit of }[1,2,3,4,5] \\
\text { (if fixed with no buffer), } \\
\text { Integrated terminal ship system }[6] \text {, } \\
\text { Offshore transshipment structure }[7,8] \\
\text { (if fixed) }\end{array}$ \\
\hline$S 9$ & $(0,1,0,0,1)$ & Y & \\
\hline$S 10$ & $(0,1,0,1,0)$ & Y & $\begin{array}{l}\text { Mobile floating crane }[9] \text {, } \\
\text { Offshore transshipment structure }[7,8] \\
\text { (if mobile), } \\
\text { Crane unit of }[1,2,3,4,5] \\
\text { (if mobile with no buffer) }\end{array}$ \\
\hline$S 11$ & $(0,1,0,1,1)$ & Y & Hybrid quay wall [11] \\
\hline$S 12$ & $(0,1,1,0,0)$ & $\mathrm{Y}$ & \\
\hline$S 13$ & $(0,1,1,0,1)$ & $\mathrm{Y}$ & \\
\hline$S 14$ & $(0,1,1,1,0)$ & $\mathrm{N}$ & \\
\hline$S 15$ & $(0,1,1,1,1)$ & $\mathrm{N}$ & \\
\hline$S 16$ & $(1,0,0,0,0)$ & Y & Static floating buffer of [1] \\
\hline$S 17$ & $(1,0,0,0,1)$ & Y & \\
\hline$S 18$ & $(1,0,0,1,0)$ & $\mathrm{Y}$ & $\begin{array}{l}\text { Feeder ship, container ship, } \\
\text { Mobile floating buffer of [1] }\end{array}$ \\
\hline$S 19$ & $(1,0,0,1,1)$ & Y & $\begin{array}{l}\text { Transfer unit of }[1,2,3,4,5,10] \text {, } \\
\text { RORO feeder ship }[12]\end{array}$ \\
\hline$S 20$ & $(1,0,1,0,0)$ & Y & \\
\hline$S 21$ & $(1,0,1,0,1)$ & Y & \\
\hline$S 22$ & $(1,0,1,1,0)$ & $\mathrm{N}$ & \\
\hline$S 23$ & $(1,0,1,1,1)$ & $\mathrm{N}$ & \\
\hline$S 24$ & $(1,1,0,0,0)$ & $\mathrm{Y}$ & $\begin{array}{l}\text { Replacement port }[13,14] \\
\text { (without land connection), } \\
\text { Floating transshipment terminal [15], } \\
\text { Crane unit of }[1,2,3,4,5] \\
\text { (if fixed with buffer) }\end{array}$ \\
\hline$S 25$ & $(1,1,0,0,1)$ & $\mathrm{Y}$ & Offshore port module of [10] \\
\hline
\end{tabular}


Table 2 continued

\begin{tabular}{|c|c|c|c|}
\hline S\# & $(B, C, L, M, R)$ & Feasible & References \\
\hline$S 26$ & $(1,1,0,1,0)$ & $\mathrm{Y}$ & $\begin{array}{l}\text { Midstream operation [16], } \\
\text { Crane unit of }[1,2,3,4,5] \\
\text { (if mobile with buffer) }\end{array}$ \\
\hline$S 27$ & $(1,1,0,1,1)$ & $\mathrm{Y}$ & Mobile harbor $[17,18,19]$ \\
\hline$S 28$ & $(1,1,1,0,0)$ & $\mathrm{Y}$ & $\begin{array}{l}\text { Replacement port }[13,14] \\
\text { (with land connection) }\end{array}$ \\
\hline$S 29$ & $(1,1,1,0,1)$ & $\mathrm{Y}$ & \\
\hline$S 30$ & $(1,1,1,1,0)$ & $\mathrm{N}$ & \\
\hline$S 31$ & $(1,1,1,1,1)$ & $\mathrm{N}$ & \\
\hline
\end{tabular}

[1]: Morrison et al. (2009b), [2]: Yoon (2008), [3]: Lee et al. (2010), [4]: Lee et al. (2009b), [5]: Kim (2009a), [6]: March (2005), [7]: Han and Kim (2009), [8]: Abdel-Maksoud and Wichner (2008), [9]: Gottwald (2010), [10]: Morrison et al. (2009a), [11]: Chae et al. (2007), [12]: Lindstad et al. (2003), [13]: Yang (2003), [14]: Yang (2009), [15]: Han et al. (2009), [16]: HKMOA (2009), [17]: Suh (2008), [18]: Yang et al. (2009b), [19]: Yang (2009)

Table 3 Combinations of the structures of Table 2

\begin{tabular}{lll}
\hline$C \#$ & Structures & References \\
\hline$C 1$ & $S 8, S 16, S 19$ & CUTU+floating buffer \\
$C 2$ & $S 19, S 25$ & Hybrid mobile floating port [1] \\
$C 3$ & $S 1, S 3, S 8, S 10, S 16, S 18, S 19$ & Modular concept [2] \\
$C 4$ & $S 8, S 19$ & CUTU [3, 4, 5, 6] \\
\hline
\end{tabular}

[1]: Morrison et al. (2009a), [2]: Morrison et al. (2009b), [3]: Yoon (2008), [4]: Lee et al. (2010), [5]: Lee et al. (2009b), [6]: Kim (2009a)

The operational modes are described next.

\subsubsection{Transport containers between ports}

An offshore structure with $M=1$ and $B=1$ may be used as a feeder ship between hub and local ports, e.g., $S 18$ (feeder ship), $S 19$ (RORO feeder ship), $S 26$ (midstream operation) and $S 27$ (mobile harbor). Non-traditional (RORO) feeders may require significantly different stacking methods and equipment.

\subsubsection{Replace a traditional port}

There are three key situations in which one may seek an offshore alternative to a traditional port: prohibitively expensive berth construction costs, a collection of small ports and inaccessible geography.

Seaside land costs, and thus berth construction costs, are exceedingly high in ports such as Hong Kong. Thus, vessels that can (un)load ships offshore and use much less expensive shallow water berths have flourished (M2). These midstream 
Table 4 Relationship between operational modes and binary variables

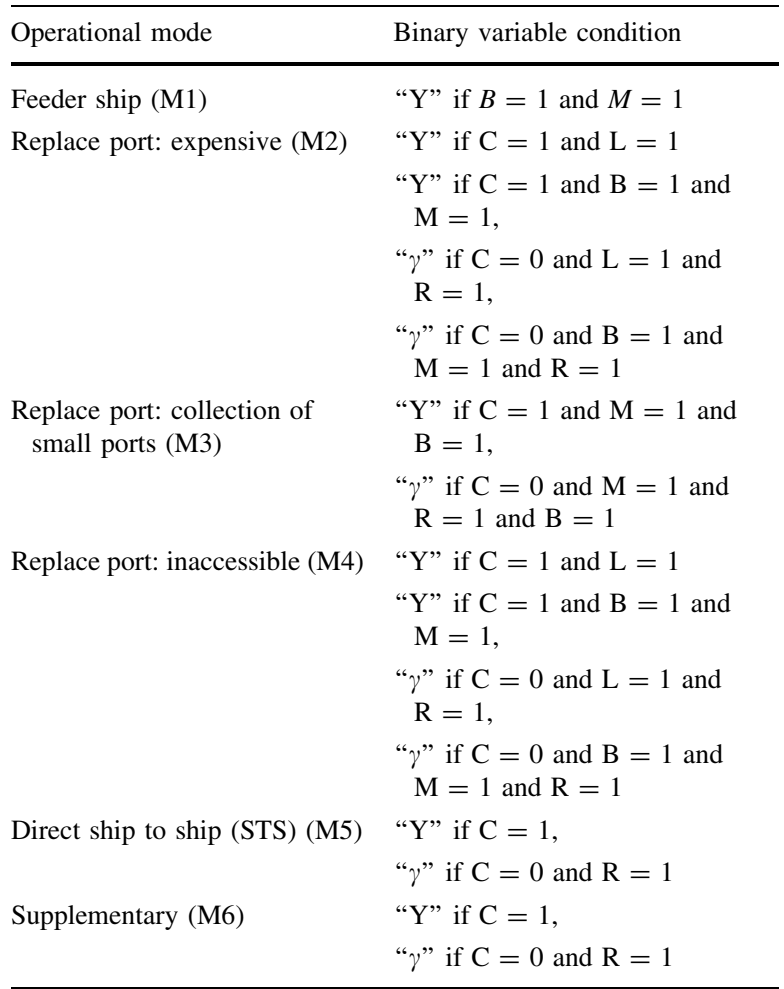

vessels are an example of $S 26$. We do not allow M2 for floating ports without a link to land, because that structure alone cannot then address import/export containers.

In Korea, nine ports had throughput under 50,000 TEU in 2010 (SPIDC 2011). A floating structure can serve such a collection of small markets (M3) by serving containerships at sea and then distributing the containers to their shallow berth destination ports. Duplicate resources such as quay cranes and deep water berths are not necessary at each port. Structures $S 26$ and $S 27$ could provide this service. $S 19$ might serve provided the containerships are RORO capable or an offshore crane is employed.

The Tanjung Perak port in Indonesia maintains a long channel for entering ships. However, it is insufficient for 5000 TEU containerships. Table 5 gives dimensions for the current channel and post-panamax container ships (4300 TEU-5400 TEU) (JICA 2007; Yang et al. 2002). To accommodate post-panamax ships in both directions will require significant additional dredging and the construction of deep

Table 5 Dimensions of Surabaya channel and postpanamax container ships

\begin{tabular}{lll}
\hline & $\begin{array}{l}\text { Surabaya } \\
\text { channel }\end{array}$ & $\begin{array}{l}\text { Post-panamax } \\
\text { container ships (m) }\end{array}$ \\
\hline Length & 25 miles & 260 \\
Width & $100 \mathrm{~m}$ & 39.4 \\
Depth & $9.5 \mathrm{~m}$ & 12.5 \\
\hline
\end{tabular}




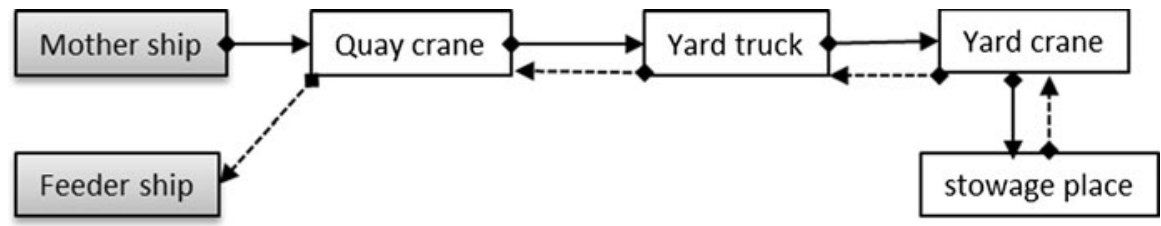

Fig. 1 Traditional ports transship containers through the yard

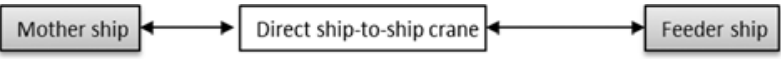

Fig. 2 Direct ship to ship transshipment avoids use of the yard

water berths. An alternate solution is to maintain the current channel, use floating structures (e.g., $S 12, S 13$ or $S 26$ ) to serve container ships in deep water, and deliver the containers to the existing shallow water berths (M4).

\subsubsection{Transfer containers from ship to ship (direct STS)}

In the traditional transhipment process, a container arrives on a ship and is stored in the yard. It is later delivered to another ship. Traditional transshipment costs US\$ 50 per TEU (Yang 2003) in Busan, South Korea. Refer to Fig. 1. Ship-to-ship (STS) transshipment transfers such containers from ship to ship via crane without a stay in the yard (M5). Refer to Fig. 2. The STS cost in Busan, South Korea, is estimated as US\$ 21.125 per TEU by assuming only crane operation costs (Yang 2003).

As discussed in personal communications with Captain Miu Sang Wong, CEO of the Hong Kong Mid-Stream Operators Association (HKMOA), 21 August 2009, STS is seldom, if ever, conducted outside of the occasional STS by midstream operators in Hong Kong (we refer to this communication as [Personal HKMOA 2009] hereafter). This is primarily because the schedule of the ships involved must be tightly coordinated; this is seldom possible.

Logistics willing, a floating structure with crane $(C=1)$ may conduct STS. For RORO ships, structures with RORO capability $(R=1)$ may support STS (a buffer or extremely well-coordinated stowage plans are required).

\subsubsection{Supplementary container (un)loading service at a traditional port}

Floating structures can supplement (un)loading resources in a traditional port (M6). A congested port can quickly deploy floating structures and reduce containership cycle time during years long berth expansion efforts. Here, the value of capacity and cycle time must be weighed against the cost of the floating structures. Floating structures with $C=1$ and $R=1$ may serve this purpose for traditional and RORO vessels, respectively. Additional features such as a buffer, mobility or connection to land may be required to enable this mode.

When a collection of floating structures acts as a berth for a containership offshore, they may be considered as an additional server. Floating structures can 
also serve as the seaside portion of a double sided (un)loading system and increase the effective service rate of each land-based berth.

\subsubsection{Operational modes for structures}

Table 6 gives the operational modes for the structures of Tables 2 and 3 based on Table 4. Only structures $S 26$ and $S 27$ can provide all operational modes. $S 27$ is a RORO capable version of $S 26$. It can opt to use its RORO capability as required. We will study $S 27$ in detail in our economic analysis.

\section{Survey of offshore operation concepts}

We next provide what is, to our knowledge, the first survey of all offshore port service concepts from the literature. The physical layout and operational features of each are discussed. The concepts are:

Table 6 Operational modes provided by offshore structures

\begin{tabular}{|c|c|c|c|c|c|c|}
\hline & M1 & M2 & M3 & M4 & M5 & M6 \\
\hline $\mathrm{S} 1$ & $\mathrm{~N}$ & $\mathrm{~N}$ & $\mathrm{~N}$ & $\mathrm{~N}$ & $\gamma$ & $\gamma$ \\
\hline $\mathrm{S} 3$ & $\mathrm{~N}$ & $\mathrm{~N}$ & $\mathrm{~N}$ & $\mathrm{~N}$ & $\gamma$ & $\gamma$ \\
\hline S5 & $\mathrm{N}$ & $\gamma$ & $\mathrm{N}$ & $\gamma$ & $\gamma$ & $\gamma$ \\
\hline S8 & $\mathrm{N}$ & $\mathrm{N}$ & $\mathrm{N}$ & $\mathrm{N}$ & $\mathrm{Y}$ & Y \\
\hline S9 & $\mathrm{N}$ & $\mathrm{N}$ & $\mathrm{N}$ & $\mathrm{N}$ & $\mathrm{Y}$ & $\mathrm{Y}$ \\
\hline $\mathrm{S} 10$ & $\mathrm{~N}$ & $\mathrm{~N}$ & $\mathrm{~N}$ & $\mathrm{~N}$ & $\mathrm{Y}$ & $\mathrm{Y}$ \\
\hline S11 & $\mathrm{N}$ & $\mathrm{N}$ & $\mathrm{N}$ & $\mathrm{N}$ & $\mathrm{Y}$ & $\mathrm{Y}$ \\
\hline $\mathrm{S} 12$ & $\mathrm{~N}$ & $\mathrm{Y}$ & $\mathrm{N}$ & $\mathrm{Y}$ & $\mathrm{Y}$ & $\mathrm{Y}$ \\
\hline $\mathrm{S} 13$ & $\mathrm{~N}$ & $\mathrm{Y}$ & $\mathrm{N}$ & $\mathrm{Y}$ & $\mathrm{Y}$ & $\mathrm{Y}$ \\
\hline S16 & $\mathrm{N}$ & $\mathrm{N}$ & $\mathrm{N}$ & $\mathrm{N}$ & $\mathrm{N}$ & $\mathrm{N}$ \\
\hline S17 & $\mathrm{N}$ & $\mathrm{N}$ & $\mathrm{N}$ & $\mathrm{N}$ & $\gamma$ & $\gamma$ \\
\hline $\mathrm{S} 18$ & $\mathrm{Y}$ & $\mathrm{N}$ & $\mathrm{N}$ & $\mathrm{N}$ & $\mathrm{N}$ & $\mathrm{N}$ \\
\hline S19 & $\mathrm{Y}$ & $\gamma$ & $\gamma$ & $\gamma$ & $\gamma$ & $\gamma$ \\
\hline $\mathrm{S} 20$ & $\mathrm{~N}$ & $\mathrm{~N}$ & $\mathrm{~N}$ & $\mathrm{~N}$ & $\mathrm{~N}$ & $\mathrm{~N}$ \\
\hline S21 & $\mathrm{N}$ & $\gamma$ & $\mathrm{N}$ & $\gamma$ & $\gamma$ & $\gamma$ \\
\hline S24 & $\mathrm{N}$ & $\mathrm{N}$ & $\mathrm{N}$ & $\mathrm{N}$ & $\mathrm{Y}$ & $\mathrm{Y}$ \\
\hline $\mathrm{S} 25$ & $\mathrm{~N}$ & $\mathrm{~N}$ & $\mathrm{~N}$ & $\mathrm{~N}$ & $\mathrm{Y}$ & $\mathrm{Y}$ \\
\hline S26 & $\mathrm{Y}$ & $\mathrm{Y}$ & $\mathrm{Y}$ & $\mathrm{Y}$ & $\mathrm{Y}$ & $\mathrm{Y}$ \\
\hline S27 & $\mathrm{Y}$ & $\mathrm{Y}$ & $\mathrm{Y}$ & $\mathrm{Y}$ & $\mathrm{Y}$ & $\mathrm{Y}$ \\
\hline S28 & $\mathrm{N}$ & $\mathrm{Y}$ & $\mathrm{N}$ & $\mathrm{Y}$ & $\mathrm{Y}$ & $\mathrm{Y}$ \\
\hline $\mathrm{S} 29$ & $\mathrm{~N}$ & $\mathrm{Y}$ & $\mathrm{N}$ & $\mathrm{Y}$ & $\mathrm{Y}$ & $\mathrm{Y}$ \\
\hline $\mathrm{C} 1$ & $\mathrm{Y}$ & $\mathrm{Y}$ & $\mathrm{Y}$ & $\mathrm{Y}$ & $\mathrm{Y}$ & $\mathrm{Y}$ \\
\hline $\mathrm{C} 2$ & $\mathrm{Y}$ & $\mathrm{Y}$ & Y & $\mathrm{Y}$ & $\mathrm{Y}$ & $\mathrm{Y}$ \\
\hline C3 & $\mathrm{Y}$ & $\mathrm{Y}$ & $\mathrm{Y}$ & $\mathrm{Y}$ & $\mathrm{Y}$ & $\mathrm{Y}$ \\
\hline $\mathrm{C} 4$ & $\mathrm{Y}$ & Y & $\mathrm{Y}$ & $\mathrm{Y}$ & Y & Y \\
\hline
\end{tabular}


- Floating cranes (Sect. 3.2),

- Floating replacement ports (Sect. 3.3),

- Floating supplementary quays (Sect. 3.4),

- Lighter aboard ship (LASH) (Sect. 3.5),

- Midstream operation (with a focus on Hong Kong) (Sect. 3.6),

- Mobile harbor (Sect. 3.7),

- Offshore transshipment structures (Sect. 3.8),

- RORO feeder ships and terminal (Sect. 3.9),

- Separated crane unit and transfer unit (Separated CUTU) (Sect. 3.10),

- Hybrid mobile floating port (Sect. 3.11), and

- Offshore modules (Sect. 3.12).

Among these concepts, midstream operation, floating cranes and LASH are existing concepts. The others are proposed concepts. We employ our classification of the previous section to help describe the capabilities of each concept.

\subsection{Advantages and disadvantages of offshore structures}

Floating structures share common advantages (Chae 2007; Yang 2003). They: (1) can be quickly deployed, removed, relocated and expanded, (2) are minimally influenced by seabed conditions, (3) require no foundation work, (4) can be set up in many locations, (5) have no ground subsidence and (6) have a low effect on the environment. Disadvantages are that they: (1) are susceptible to weather conditions, (2) may be damaged by severe waves, (3) require mooring or stabilization systems, and (4) have short life cycles and inflated operational costs.

RORO feeder ships, mobile harbors, hybrid mobile floating ports and offshore modules employ RORO systems. They are faster than cranes (Kim et al. 2010; Lindstad et al. 2003), reduce ship service time and reduce shoreline use. However, RORO has numerous requirements not present in traditional systems. Container stack height is limited and depends on land transportation systems. Connection resources (e.g., a bridge between ships and berths) and container stacking equipment are required. Detailed designs, safety, efficiency and economic and technological feasibility for RORO systems are discussed in Kim et al. (2010).

Structures that conduct offshore loading of ships using a mobile buffer with (or supported by) cranes (e.g., S26 and S27), must have carefully organized container stacks to enable correct container delivery to the destination ship. The export cargo to be delivered to the containership first should be stacked at the top of the mobile buffer to avoid extra handling. This issue need not be considered for unloading of import or transhipment containers.

\subsection{Floating cranes}

Container cranes on a mobile floating structure are called floating cranes $(S 10)$; c.f. (Gottwald 2010). They are used to transfer cargo between ships or from ship to land. They often rely on a tugboat and seldom host a container buffer. Operational modes are listed in Table 6. They have been employed for open sea (35 km from the shore) 
transshipment between ships in Indonesia and can work in winds up to force $9 \mathrm{Bft}$ with waves up to $2.5 \mathrm{~m}$ high at maximum (Gottwald 2010).

\subsection{Floating replacement port}

A floating replacement port is essentially a traditional land-based port on a floating structure; see Yang (2003) and Yang et al. (2009a). It hosts a container yard, quay cranes and berths; it is an example of $S 24$. It may also be $S 28$ if there is a bridge connecting it to land. Yangshan port (Zhao 2006) in China is connected to the mainland via a bridge and is similar to $S 28$ though it is built on an island. A floating port will be more expensive than a land based port (Yang 2003). Operational modes for S24 and S28 are given in Table 6.

\subsection{Floating supplementary quays}

Floating supplementary quays are positioned adjacent to or very near to an existing land-based quay. They move alongside a containership and use their cranes to supplement the land based cranes or entirely replace them.

In Chae (2007), an S11 structure is called a hybrid quay wall (HQW); see Fig. 3. It is positioned by tug boats on the opposite side of the containership from the land berth and enables double-sided unloading (mode M6). Retractable bridges at the fore and aft of the structure allow trucks with containers to enter and exit (this is the RORO transfer). The containers are placed on the trucks when they are unloaded from the ship (similarly for loading). The opposite side of the HQW may be used to serve feeder ships and thus enable direct ship-to-ship service (mode M5). Simulations were conducted in Chae (2007) to determine the working conditions for the HQW; it can operate in weather conditions typical of the port in Busan, South Korea.

In March (2005), an S8 is termed an Integrated Terminal Ship System (ITSS); see Fig. 4. It consists of two parallel, floating, narrow and $450 \mathrm{~m}$ long finger piers connected via above-ship (un)loading bridges that serve as cranes. One finger pier is adjacent to the land berth. The distance between the finger piers can be adjusted by a floating connector between them (it does not serve as a bridge for RORO). Ships may berth outside or between the finger piers. STS is possible when multiple ships are berthed at the ITSS. It could be used in modes M5 and M6.

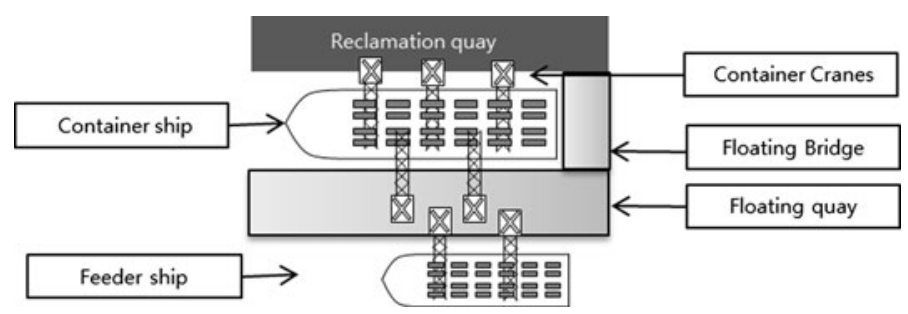

Fig. 3 Overhead view of a hybrid quay wall (HQW) 


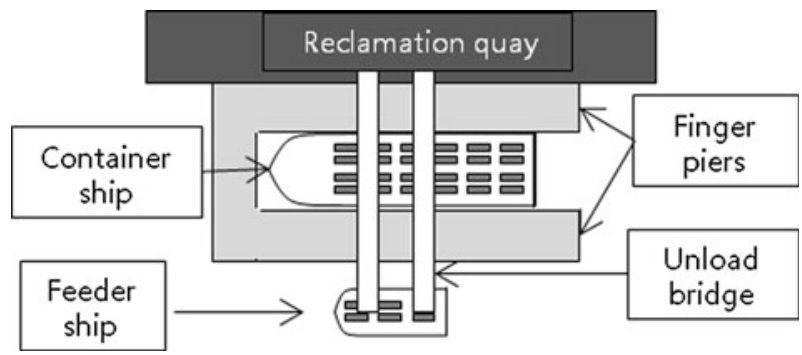

Fig. 4 Overhead view of the Integrated Terminal Ship System (ITSS)

\subsection{Lighter aboard ship (LASH)}

Another concept is to load small barges called lighters with containers and then load these lighters aboard another larger ship. This concept is mentioned in Minchin (2006), Lewis (2003) and Sanyal (2002). The larger ship is termed a LASH vessel, for lighter aboard ship; it is partially submersible. When the lighters are ready to board the LASH vessel, the LASH loading area submerges, the lighters are moved above the loading area and the loading area is raised from the water. While aboard the LASH vessel, the lighters enjoy protection from the seas. At its destination, the LASH vessel releases the lighters; they are moved to their destination. There is no need for transshipment of the containers. In contrast, the traditional approach would be to load a large feeder ship with all of the containers and then transship those containers to lighters at some intermediate port. LASH vessels are economical only in certain special situations.

LASH vessels can be covered by our classification by extending the buffer variable $B$ to allow buffering of ships. Since LASH vessels are not in common use, we do not employ such an extension.

\subsection{Midstream operations in Hong Kong}

While most ports serve container ships at a sea-side berth, approximately $10 \%$ of container (un)loading at Hong Kong is conducted offshore in mode M2 (HKMOA 2009). These midstream operations have been conducted at many locations. Currently, Hong Kong is the primary location for midstream operations.

There are two essential elements of midstream operations. The first is $S 26$, a movable container barge with its own derrick crane, or lighter. The second is a shallow $5 \mathrm{~m}$ water depth berth. Figure 5 depicts lighters unloading a containership at sea (overhead view). The central containership is served by eight rectangular lighters. The tiny grey rectangles represent containers. To (un)load a containership offshore, multiple lighters are positioned alongside the containership by tugboats. They are all secured via a wire and winch system. Typically, several lighters are placed side by side at increasing distance from the containership. The lighters adjacent to the ship serve as cranes and transfer containers between the container ship and the exterior lighters. When those exterior lighters are full/empty, the ones 


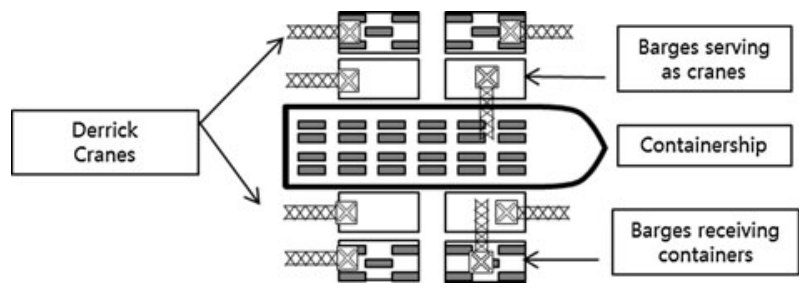

Fig. 5 Midstream barges alongside a containership in Hong Kong

adjacent to the containership use their derrick crane to serve themselves. Tugboats transport the container laden lighters back to their shallow water berth. The lighters then use their own derrick crane to (un)load the containers at the berth.

Midstream operation is limited by weather conditions, has a greater incidence of personal injury and death, damages a greater portion of containers and conducts ship (un)loading $1 / 2$ as quickly as traditional quay cranes. The size of containerships served is limited to 4000 TEU by the derrick cranes.

Despite these inherent weaknesses, midstream operations enjoy a particular confluence of factors in Hong Kong where port expansion is limited by geography. Midstream barges require only $5 \mathrm{~m}$ depth shallow water berths and thus charge $1 / 3$ the container handling fee of the traditional Hong Kong port. Their terminals can be constructed in much less time than a traditional berth. Midstream lighters (S26) can conceivably conduct all of modes M1,.., M6.

The preceding description is derived from [Personal HKMOA 2009].

\subsection{Mobile harbor}

The mobile harbor (MH) or mobile floating port, first proposed in Suh (2008), is $S 27$ - a self mobile barge with container buffer, onboard quay crane(s) and RORO capability. It combines a RORO feeder ship (S19) and a midstream lighter (S26). Existing designs call for capacities between 250 and 1200 TEU (MHBT 2011). The onboard cranes may have adjustable height and length (Yang 2009; Yang et al. 2009 b) and can be used either to (un)load containerships or (un)load the mobile harbor at port. Containers may be (un)loaded via RORO at a RORO capable landbased port. The containers may be stored on wheeled palates on the barge and rolled off via self-propelled AGVs, rails or a hydraulic system (Hydrospex 2011). The working condition for $\mathrm{MH}$ is sea state three at maximum (Pierson 2011). Figure 6 shows a collection of mobile harbors serving a containership and traveling between the ship and a RORO capable land-based port. The MH may support modes M1 ,.., M6.

\subsection{Offshore transshipment structures}

In Han and Kim (2009), a movable floating structure with container cranes was proposed for STS (mode M5); see Fig. 7. It is $S 10$ if mobile and $S 8$ if not. It differs from floating cranes in that it supports numerous cranes and is intended solely for 


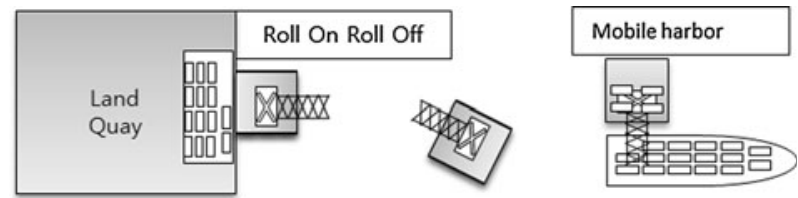

Fig. 6 A top view of mobile harbors providing service to a containership offshore

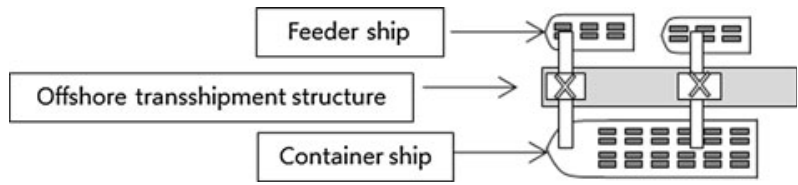

Fig. 7 The offshore transshipment structure enables ship to ship container transfer

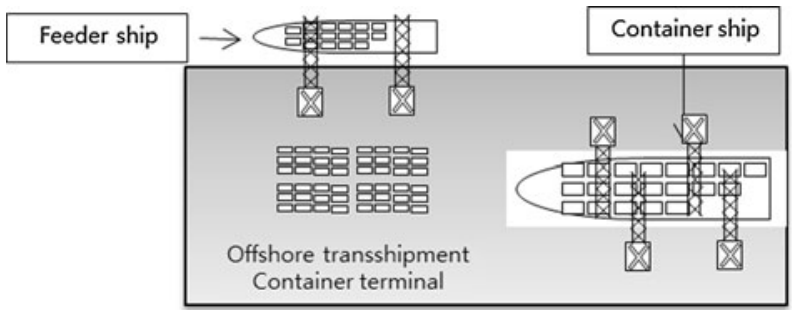

Fig. 8 The floating transshipment container terminal primarily provides ship to ship service, but may store containers

STS. There is typically no buffer. A similar concept that allows ships to berth outside or between two external floating structures (possibly connected underneath the sea) was proposed in Abdel-Maksoud and Wichner (2008) for STS (Mode 5). Mode M6 may be possible.

The floating transshipment container terminal proposed in Han et al. (2009) is larger than the two previous transshipment structures and includes a buffer, see Fig. 8. It is $S 24$. Its primary function is for quick STS (mode M5) but it provides all functions of a container port. Indented berths can enable double-sided (un)loading. Mode M6 may be possible.

\subsection{RORO feeder ships and terminal}

RORO container ships (S19) termed Interbarge and Enisys and a RORO terminal termed improved port/ship interface (IPSI) were proposed in Lindstad et al. (2003). There, containers are stacked onto rolling palates using straddle carriers or yard cranes. These loaded palates are rolled onto and off of the RORO ships with the help of automatic guided vehicles (AGVs) or trucks. No container cranes are used. The RORO vessels act as feeder ships; the remainder of the container handling chain is unchanged. Table 6 gives operational modes. 


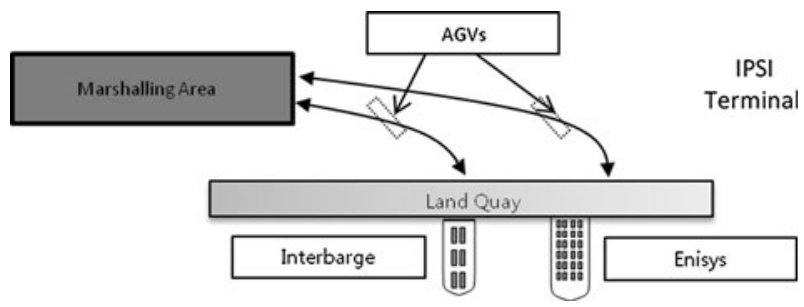

Fig. 9 The IPSI terminal accommodates RORO feeder ships. Inspired by Lindstad et al. (2003)

The IPSI is depicted in Fig. 9. AGVs access the RORO feeder ships and move containers between the RORO ships and a marshalling area where the palates are (un)loaded. Straddle carriers are used to transport containers from the marshalling area to the landside input/output area of the port. RORO ships and the berths are connected via a RORO interface.

\subsection{Separated crane unit and transfer unit (separated CUTU)}

As shown in Fig. 10, the mobile harbor can be separated into $S 8$ or $S 10$ (a floating crane unit (CU)) and $S 19$ (a RORO capable self-mobile barge called a transfer unit (TU)); refer to Kim (2009a), Lee et al. (2009b), Lee et al. (2010) and Yoon (2008). Modes M1 ,.., M6 can be provided.

The TU can serve as a container buffer or a floating buffer can be set up adjacent to the CUs. Cargo destined for another ship (as opposed to inland) can be temporarily stored in the buffer and loaded to the destination ship offshore; see Fig. 11.

\subsection{Hybrid (mobile) floating port}

In Morrison et al. (2009a), S19 structures (RORO feeder ships (TUs)) are combined with a floating replacement port $S 25$; see Fig. 12. This hybrid floating port (HFP) has a RORO interface for TUs. The TUs shuttle containers between land-based ports and the HFP for import/export cargo. Unlike the replacement port, TUs are used instead of a bridge to the land. The system may be mobile. Modes M1 ,.., M6 may be supported.
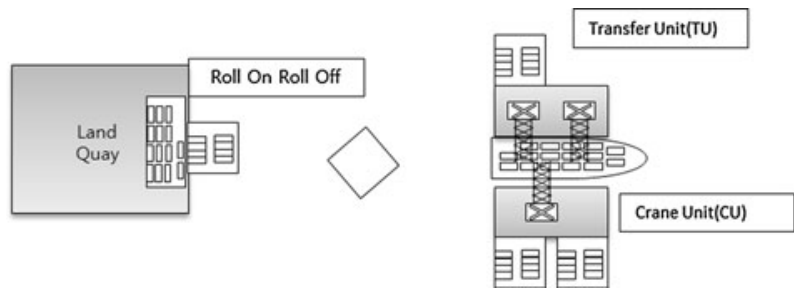

Fig. 10 Overhead view of a separated CUTU system with crane units and transfer units 

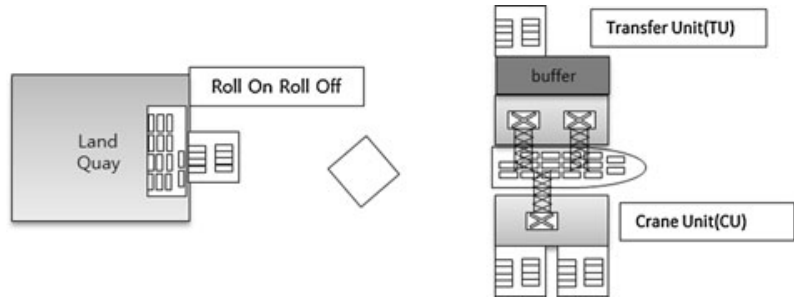

Fig. 11 An offshore container buffer may be used to supplement the CUTU system

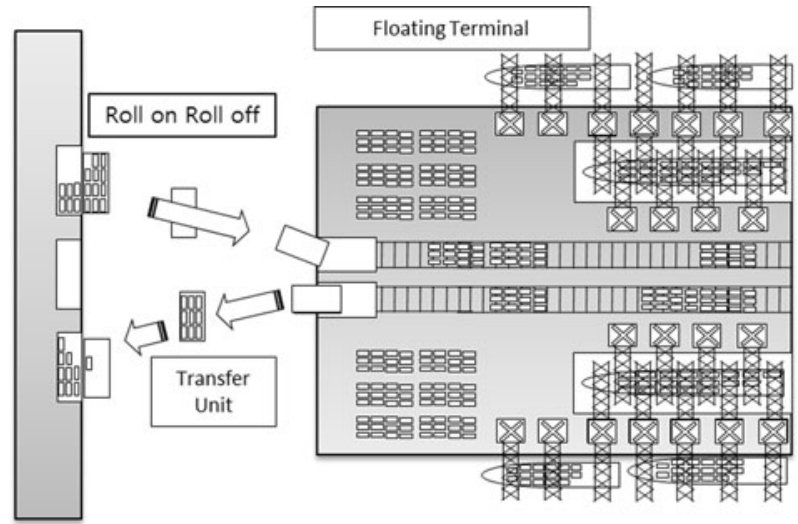

Fig. 12 Overhead view of the hybrid floating port

\subsection{Offshore modules}

The offshore modules proposed in Morrison et al. (2009b) allow for a combination of the above $\mathrm{CU}$, TU and hybrid floating port concepts. There are four modules proposed: crane module $S 8$ or $S 10$, transfer module (with RORO capability) $S 19$, buffer module $S 16$ or $S 18$ and RORO interface module $S 1$ or $S 3$ for the berth. Numerous structures can be generated by the combination of one or more of these modules as desired. For example, the separated CUTU consists of a crane module, a transfer module and a RORO interface at the berth.

\subsection{Container handling chain $(\mathrm{CHC})$ of offshore concepts}

The container handling chain $(\mathrm{CHC})$ may be different when using floating structures. To illustrate the differences, we describe the traditional and floating structure $\mathrm{CHCs}$ for import cargo arriving via containership. Refer to Table 7 for the CHC of floating structures in modes M2, M3, M4 and M6. There, starting from the arriving container ship (CS), the CHC proceeds from left to right. After the yard, the container proceeds to the hinterland. LASH is not considered. Offshore modules are too flexible to be described in general. 


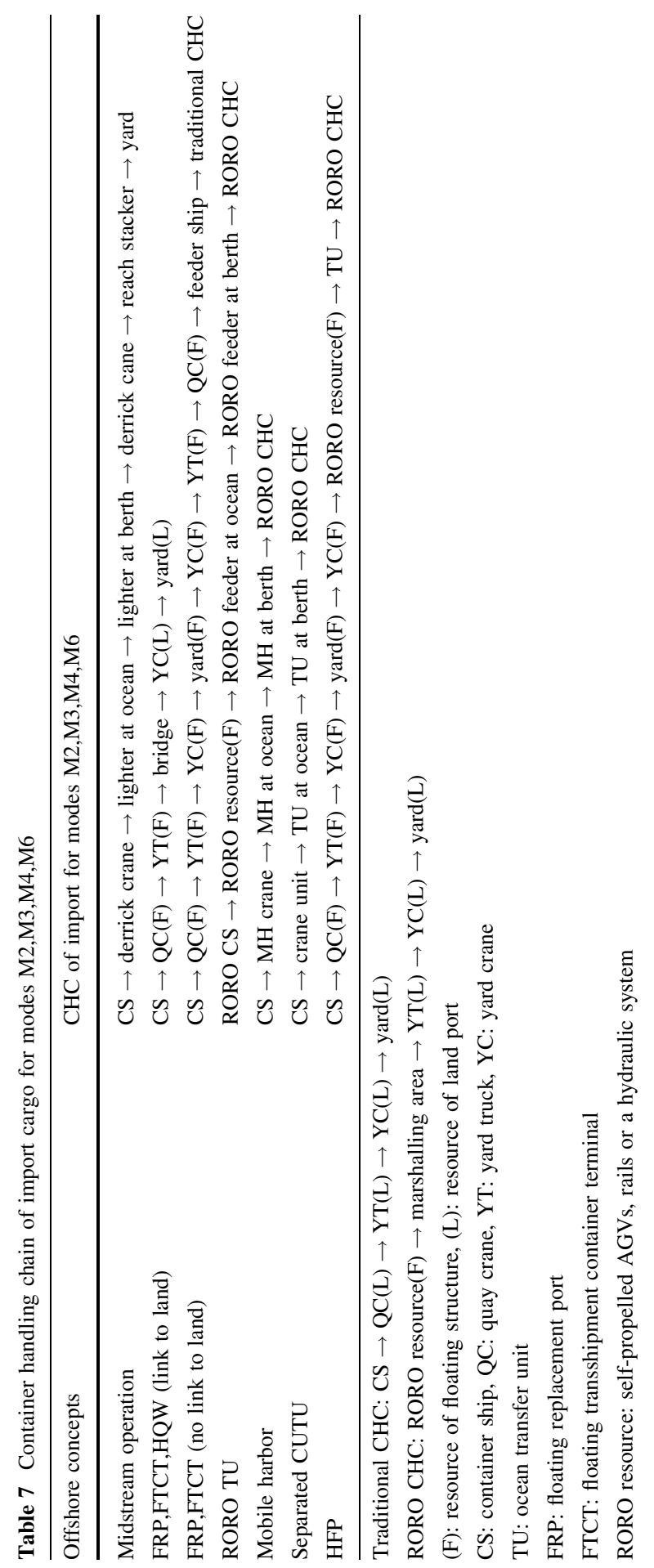


The container handling chain for import cargo to a traditional port consists of container: (1) unloading from the ship to a truck via quay crane, (2) transfer from the berth to the yard via yard truck, and (3) stacking in the yard from the yard truck via a yard crane (thereafter it proceeds to the hinterland). The handling chain for export cargo is the reverse.

In $\mathrm{M} 1$, the arriving containership is the floating resource. If it uses port cranes to unload, the CHC is traditional. If it uses its own onboard crane, the $\mathrm{CHC}$ is still traditional, except the crane is onboard the ship. If it uses RORO for the containers, the $\mathrm{CHC}$ is given in Table 7 as RORO CHC starting immediately at the feeder (add "feeder $\rightarrow$ " in front of the RORO CHC).

For M2, M3 and M4 the containership arrives to a floating replacement for a port. The CHC for midstream operation, floating replacement port (FRP)/floating transshipment container terminal (FTCT) with and without a link to land, HQW, offshore transfer to a RORO TU (assuming RORO containership), MH, separated CUTU and HFP are given in Table 7. For floating cranes, they simply replace any other crane in the $\mathrm{CHC}$ when they are used. Note that for M3, each container may be destined for a different port. Thus, care must be taken to collect containers by their destination.

The container handling chain for offshore concepts conducting ship to ship (mode M5) was discussed in Sect. 2.2.3.

For mode M6, the $\mathrm{CHC}$ for those import containers handled by the supplementary floating structure is the same as for M2, M3, M4 described above.

Export and transshipment cargo are similar. For an offshore structure with a buffer, transshipment cargo may wait there for its next journey.

\section{Data collection and preparation}

In the sequel, we turn our attention to the economic study of S27; we require cost and operation data. For consistency, we will convert all data obtained into 2011 US\$ by assuming an annual 4\% inflation rate and conversion rates of KRW 1140 (Korean Won) and HKD 7.78 (Hong Kong dollars) to US\$ 1, respectively (based on January 2011 conversion rates). For example, the cost of a $300 \mathrm{~m}$ traditional berth in Hong Kong was HKD 1350 million in 2000. Multiplying by $(1.04)^{11}$, this is equivalent to HKD 2,080 million in 2011 or US\$ 266 million in 2011.

We will convert all costs to a yearly cost per resource. The yearly cost is the sum of the annual depreciation of purchase/construction cost and annual operation costs. Using linear depreciation (straight line method) (Sullivan et al. 2003) with near zero value at the end of life, the annual depreciation is calculated as the purchase/ construction cost divided by the Prediction of Life Cycle (PoLC). In conceptual design material by Marine Technology \& Information Co., Ltd, 21st Century Shipbuilding Co., Ltd in 2009 (we will hereafter refer to this material as [MH design 2009]), the mobile harbor PoLC was estimated as 20 years. We will assume that the PoLC is 20 years for all equipment considered. In a 2009 report by the KAIST mobile harbor team (we will hereafter refer to this report as [MH report 2009]), the yearly operation cost, including labor, maintenance, power, terminal handling 
charges (not including container handling, but only the berthing costs) and insurance, is estimated as $13 \%$ of the purchase cost of a $\mathrm{MH}$. We will use this figure for all equipment. (Note that berths have yearly dredging costs instead of terminal handling costs.) For example, the yearly resource cost of a $300 \mathrm{~m}$ traditional berth in Hong Kong in 2011 US\$'s is $(266 / 20)+(266 \times 0.13)=48.0$ million US\$.

The cost data obtained from JICA (2007), [Personal HKMOA 2009], [MH report 2009] and personal communications with Sungok Jeong, deputy head of the Mobile Harbor Corporation, Daejeon, South Korea, 8 December 2010 (we refer to this communication as [Personal MH 2010] hereafter) is given in Table 8. Each value in the table is either directly from a reference, estimated or calculated as indicated by a superscript numerical value, "E" or "C". Data from a reference is the exact figure from that source. "E" values have been estimated based on source data. In particular, the construction cost in the year 2000 for the $40 \mathrm{~m}$ and $80 \mathrm{~m}$ Hong Kong market berths is assumed to be proportional to the length of the berth; it is $2 / 3$ and $4 / 3$ times the cost of the $60 \mathrm{~m}$ berth, respectively. The 600 TEU feeder ship cost is estimated at $90 \%$ of the year 2006 US $\$ 15.5$ million cost of a 660 TEU feeder ship from Wright (2010). The costs of the 250 TEU and 1,200 TEU feeder ships are estimated to be $1 / 3$ and 1.5 times the cost of the 600 TEU feeder ship, respectively. The $1 / 3$ and 1.5 factors are based on the cost ratios of the 250 TEU and 1,200 TEU mobile harbor to 600 TEU mobile harbor, respectively. The "C" data is calculated from the source data and/or estimated data using the corrections for yearly inflation and currency exchange given above.

Note that the yearly resource cost in Table 8 is only a portion of the yearly cost of the port. Since we are comparing offshore systems and berths, we choose not to include yard costs (e.g., yard crane, storage space, trucks, employees, etc.); they are nominally the same for all land-based berth systems.

The operation data obtained from Im (2008), [Personal HKMOA 2009], [MH design 2009], [MH report 2009] and [Personal MH 2010] is given in Table 9. Each value in the table is either directly from a reference (in which case it is labeled with a numerical value) or it is estimated (and labeled with an "E"). The 600 TEU and 1,200 TEU feeder ships are estimated to have the same speed as the 250 TEU feeder ship. We assume that single crane (un)loading at a land-based berth has maximum speed of $67.5 \mathrm{TEU} / \mathrm{h}$; see MMAFK (2001). This speed represents mechanical ideal speed. The actual operation speed is approximately $1 / 2$ of the ideal speed or 31.8 TEU/hour; this is obtained by applying a resource efficiency coefficient $(0.471)$ which we detail in Sect. 5.2.3.

The (un)loading speed is doubled when two cranes are used, as is the case for the 1,200 TEU feeder ship and mobile harbor. (The 1,200 TEU feeder ship is typically served by two quay cranes, while the 1,200 TEU mobile harbor possess two of its own cranes. The smaller mobile harbors only have a single on-board crane.) The RORO container (un)loading speed for the 600 TEU and 1,200 TEU mobile harbors is increased by 1.5 and 2 times, respectively, over the 250 TEU mobile harbor. This scaling is based on the width and stack heights of the mobile harbors as specified by their designs [MH report 2009].

The data of Table 8 for Hong Kong is quoted from [Personal HKMOA 2009] and used to calculate $\mathrm{MH}$ viability. The container handling charge of the Hong Kong 
Table 8 Cost data for offshore structures and associated berths

\begin{tabular}{|c|c|c|c|c|}
\hline \multirow{2}{*}{$\begin{array}{l}\text { Resource } \\
\text { Berth: } 300 \text { m length, } 15 \text { m depth, } 4 \text { quay } \\
\text { cranes (Hong Kong) }\end{array}$} & \multicolumn{3}{|c|}{ Construction cost (millions) } & \multirow{2}{*}{$\frac{\text { YRC }}{48.0^{c}}$} \\
\hline & $\begin{array}{l}\text { HK\$ } 1,350^{1} \\
(2000)\end{array}$ & $\begin{array}{l}\text { US\$ } 173^{C} \\
(2000)\end{array}$ & $\begin{array}{l}\text { US\$ } 266^{C} \\
(2011)\end{array}$ & \\
\hline $\begin{array}{l}\text { Berth: } 300 \mathrm{~m} \text { length, } 15 \mathrm{~m} \text { depth, } 3 \text { quay } \\
\text { cranes (Surabaya) }\end{array}$ & & $\begin{array}{l}\text { US\$ } 113^{2} \\
(2007)\end{array}$ & $\begin{array}{l}\text { US\$ } 132^{C} \\
(2011)\end{array}$ & $23.7^{C}$ \\
\hline $\begin{array}{l}\text { Berth: } 40 \text { m length, } 5 \mathrm{~m} \text { depth, no quay } \\
\text { cranes (Hong Kong) }\end{array}$ & $\begin{array}{l}\operatorname{HK} \$ 49.5^{E} \\
(2000)\end{array}$ & $\begin{array}{l}\text { US\$ } 6.5^{C} \\
(2000)\end{array}$ & $\begin{array}{l}\text { US\$ } 10^{C} \\
(2011)\end{array}$ & $1.8^{C}$ \\
\hline $\begin{array}{l}\text { Berth: } 60 \text { m length, } 5 \mathrm{~m} \text { depth, no quay } \\
\text { cranes (Hong Kong) }\end{array}$ & $\begin{array}{l}\text { HK\$ } 75^{1} \\
(2000)\end{array}$ & $\begin{array}{l}\text { US\$ } 9.7^{C} \\
(2000)\end{array}$ & $\begin{array}{l}\text { US\$ } 15^{C} \\
(2011)\end{array}$ & $2.7^{C}$ \\
\hline $\begin{array}{l}\text { Berth: } 80 \text { m length, } 5 \mathrm{~m} \text { depth, no quay } \\
\text { cranes (Hong Kong) }\end{array}$ & $\begin{array}{l}\mathrm{HK} \$ 99^{E} \\
(2000)\end{array}$ & $\begin{array}{l}\text { US\$ } 13^{C} \\
(2000)\end{array}$ & $\begin{array}{l}\text { US\$ } 20^{C} \\
(2011)\end{array}$ & $3.6^{C}$ \\
\hline Feeder: 250 TEU & & & $\begin{array}{l}\text { US\$ } 5.7^{E} \\
(2011)\end{array}$ & $1.0^{C}$ \\
\hline Feeder: 600 TEU & & $\begin{array}{l}\text { US\$ } 13.95^{E} \\
(2006)\end{array}$ & $\begin{array}{l}\text { US\$ } 17^{\mathrm{C}} \\
(2011)\end{array}$ & $3.1^{C}$ \\
\hline Feeder: 1200 TEU & & & $\begin{array}{l}\text { US\$ } 25.5^{E} \\
(2011)\end{array}$ & $4.6^{C}$ \\
\hline Lighter: 250 TEU & & $\begin{array}{l}\text { US\$ } 1^{1} \\
(2000)\end{array}$ & $\begin{array}{l}\text { US\$ } 1.6^{C} \\
(2011)\end{array}$ & $0.3^{C}$ \\
\hline MH: 250 TEU Crane only & $\begin{array}{l}\text { KRW } 20000^{3} \\
(2011)\end{array}$ & & $\begin{array}{l}\text { US\$ } 17.5^{C} \\
(2011)\end{array}$ & $3.1^{C}$ \\
\hline MH: 250 TEU RORO only & $\begin{array}{l}\text { KRW } 20000^{3} \\
(2011)\end{array}$ & & $\begin{array}{l}\text { US\$17.5 } \\
(2011)\end{array}$ & $3.1^{C}$ \\
\hline MH: 250 TEU, Crane \& RORO & $\begin{array}{l}\text { KRW } 30000^{3} \\
(2011)\end{array}$ & & $\begin{array}{l}\text { US\$26.3 } \\
(2011)\end{array}$ & $4.7^{C}$ \\
\hline MH: 600 TEU Crane only & $\begin{array}{l}\text { KRW } 40000^{4} \\
(2011)\end{array}$ & & $\begin{array}{l}\text { US\$ } 35^{C} \\
(2011)\end{array}$ & $6.3^{C}$ \\
\hline MH: 600 TEU RORO only & $\begin{array}{l}\text { KRW } 45000^{4} \\
(2011)\end{array}$ & & $\begin{array}{l}\text { US\$ } 39.5^{C} \\
(2011)\end{array}$ & $7.1^{C}$ \\
\hline MH: 600 TEU, Crane \& RORO & $\begin{array}{l}\text { KRW } 55000^{4} \\
(2011)\end{array}$ & & $\begin{array}{l}\text { US\$ } 48.2^{C} \\
(2011)\end{array}$ & $8.7^{C}$ \\
\hline MH: 1200 TEU Crane only & $\begin{array}{l}\text { KRW } 65000^{4} \\
(2011)\end{array}$ & & $\begin{array}{l}\text { US\$ } 57^{C} \\
(2011)\end{array}$ & $10.3^{C}$ \\
\hline MH: 1200 TEU RORO only & $\begin{array}{l}\text { KRW } 65000^{4} \\
(2011)\end{array}$ & & $\begin{array}{l}\text { US\$57 } \\
(2011)\end{array}$ & $10.3^{C}$ \\
\hline MH: 1200 TEU, Crane \& RORO & $\begin{array}{l}\text { KRW } 85000^{4} \\
(2011)\end{array}$ & & $\begin{array}{l}\text { US\$ } 74.5^{C} \\
(2011)\end{array}$ & $13.4^{C}$ \\
\hline
\end{tabular}

YRC term yearly resource cost (2011 US\$, millions)

1 Data from [Personal HKMOA 2009]

2 Data from JICA (2007)

3 Data from [MH report 2009]

4 Data from [Personal MH 2010]

$E$ Denotes estimated cost (based on similarity with other structures)

C Denotes calculated cost (based on data from literature and estimated data) 
Table 9 Operational data for feeder ships, lighters and mobile harbors

\begin{tabular}{lllll}
\hline Resource & $\begin{array}{l}\text { Travel speed } \\
(\mathrm{km} / \mathrm{h})\end{array}$ & $\begin{array}{l}\text { Crane speed at } \\
\text { berth (TEU/h) }\end{array}$ & $\begin{array}{l}\text { Crane speed on } \\
\text { ocean (TEU/h) }\end{array}$ & $\begin{array}{l}\text { RORO speed at } \\
\text { berth (TEU/h) }\end{array}$ \\
\hline $\begin{array}{l}\text { Feeder 250 TEU } \\
\text { capacity }\end{array}$ & $18.52^{[1]}$ & $67.5^{E}$ & & \\
$\begin{array}{l}\text { Feeder 600 TEU } \\
\text { capacity }\end{array}$ & $18.52^{E}$ & $67.5^{E}$ & & \\
$\begin{array}{l}\text { Feeder 1200 TEU } \\
\text { capacity }\end{array}$ & $18.52^{E}$ & $135^{E}$ & & \\
$\begin{array}{l}\text { Lighter 250 TEU } \\
\text { capacity }\end{array}$ & $14.82^{[2]}$ & $30^{[2]}$ & $30^{[2]}$ & $120^{[4]}$ \\
$\begin{array}{c}\text { MH 250 TEU } \\
\text { capacity }\end{array}$ & $14.82^{[3]}$ & $67.5^{E}$ & $67.5^{E}$ & $180^{E}$ \\
$\begin{array}{l}\text { MH 600 TEU } \\
\text { capacity }\end{array}$ & $14.82^{[3]}$ & $67.5^{E}$ & $67.5^{E}$ & $240^{E}$ \\
$\begin{array}{l}\text { MH 1200 TEU } \\
\text { capacity }\end{array}$ & $14.82^{[3]}$ & $135^{E}$ & $135^{E}$ & \\
\hline
\end{tabular}

[1]: Im (2008), [2]: [Personal HKMOA 2009], [3]: [Personal MH 2010], [4]: [MH report 2009]

terminal is US\$ 214 per TEU; this is scaled from 2007 data (Kim et al. 2007). As we will discuss in Sect. 5.4.1 the calculated container handling cost from ship to quay is US\$ 60.46 per TEU using our industry standard approach and safety coefficient. In Marco (2007), they argue that $40 \%$ of the container handling cost in deep-sea terminals is incurred by movement from vessel to berth (based on port experts from Rotterdam port authority and Delft University of Technology). As 40\% of US\$ 214 is US\$ 85.6, our calculated value of US\$ 60.46 (based on actual port construction cost data) seems reasonable. The difference (US\$25.14) is because we have not considered the port's container handling profit per TEU.

\section{Economic analysis of the mobile harbor}

We now turn our focus to the mobile harbor $S 27$ with $(B, C, L, M, R)=$ $(1,1,0,1,1)$ and attempt to answer the following fundamental question. "Should such a concept be implemented?" We employ standard port capacity planning methods and consider whether the mobile harbor is more economical than traditional methods for each operational mode.

We review technical feasibility, standard capacity planning models, economic feasibility and conduct sensitivity analysis in the following subsections.

\subsection{Technical matters}

Current mobile harbor designs possess the dimensions provided in Table $10[\mathrm{MH}$ report 2009]. The crane height and outreach are measured above the deck and from the edge, respectively. A diagram from [MH report 2009] is provided in Fig. 13. 
Table 10 Physical dimensions of the mobile harbor

\begin{tabular}{lllllll}
\hline Resource & $\begin{array}{l}\text { Mooring depth } \\
(\mathrm{m})\end{array}$ & $\begin{array}{l}\text { Length } \\
(\mathrm{m})\end{array}$ & $\begin{array}{l}\text { Width } \\
(\mathrm{m})\end{array}$ & $\begin{array}{l}\text { Height } \\
(\mathrm{m})\end{array}$ & $\begin{array}{l}\text { Crane height } \\
(\mathrm{m})\end{array}$ & $\begin{array}{l}\text { Crane outreach } \\
(\mathrm{m})\end{array}$ \\
\hline $\begin{array}{c}\text { MH 250 TEU } \\
\text { capacity }\end{array}$ & $5-7$ & 77.0 & 33.0 & 11.0 & 35.0 & 37.0 \\
$\begin{array}{c}\text { MH 600 TEU } \\
\text { capacity }\end{array}$ & $5-7$ & 169.7 & 32.0 & 9.5 & 29.6 & 36.0 \\
$\begin{array}{c}\text { MH 1200 TEU } \\
\text { capacity }\end{array}$ & $5-7$ & 167.7 & 41.0 & 9.5 & 39.1 & 36.0 \\
\hline
\end{tabular}

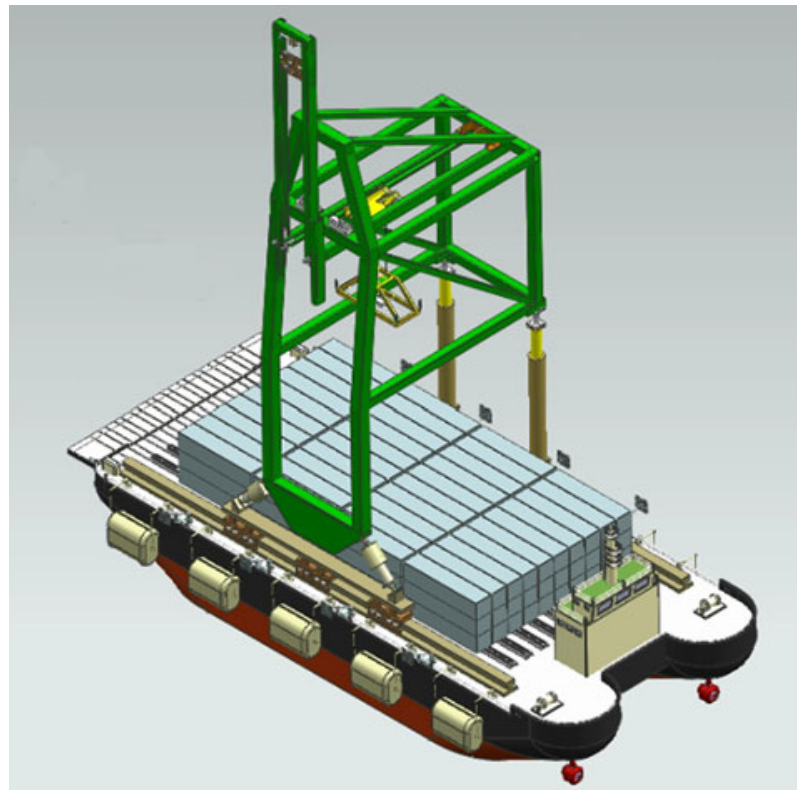

Fig. 13 Mobile harbor with 250 TEU carrying capacity [MH report 2009]

The technology required for the RORO capable and quay crane laden structure is non-trivial. We next discuss efforts to address technical aspects of the mobile harbor. The technology for offshore operation includes the crane, docking and stabilization systems.

The crane balance technology equilibrates the crane independent of vibrations in the floating structure on which it is mounted (Jung and Kwak 2009; Kwak and Oh 2009). The spreader stabilization technology assists in the automatic capture of containers using container markings and a vision system on the spreader (Han and Lee 2009; Kim et al. 2009). The goal of these technologies are to mimic the conditions faced by a land based crane operator while on the ocean.

To reduce the relative motion between the mobile harbor and a container ship on the ocean, a robot arm docking system is suggested in Lee et al. (2009a) and Shin 
et al. (2009). The function is similar to the commonly employed Automated Mooring System (AMS) (Cavotec 2011).

In Jeong et al. (2010), a mooring system for stabilization between a containership and a mobile harbor is analyzed. The motion response of mono hull and catamaran type mobile harbors moored with containerships is analyzed in Kim (2009b). A structure consisting of an upper deck, bottom deck (in the water) and vibration isolation between decks is suggested in Suh (2009).

\subsection{Standard approaches to port capacity planning}

The United Nations UNCTAD standards (UNCTAD 1985), Ministry of Maritime Affairs and Fisheries of Korea (MMAFK 2001) port development plan, Yang et al. (2001) and KCTA (2008), among others, employ similar approaches to the calculation of port resources required to meet a target capacity. We use an equivalent based on these and the model of Talley (2006).

\subsubsection{Model and LP solution}

The basic model for port design in Talley (2006) minimizes cost subject to achieving container target throughput $\lambda_{\text {tgt }}$. Their non-linear program is essentially

$$
\begin{aligned}
& \operatorname{Min} \sum_{i \in \Omega} c_{i} \cdot n_{i} \\
& \text { subject to } \\
& \lambda_{\text {tgt }} \leq f_{i}\left(n_{i}\right), n_{i} \geq 0, \forall i \in \Omega .
\end{aligned}
$$

where $\Omega$ is the set of all container handling systems in the port, $c_{i}$ is the yearly cost of a unit resource of system $\mathrm{i}$, and the decision variables $n_{i}$ are the number of units of resources in system $\mathrm{i}$. The function $f_{i}$ relates the resources in system $\mathrm{i}$ to the desired $\lambda_{\text {tgt }}$. They may be nonlinear functions. One may also restrict $n_{i}$ to be integers.

It is common in industry (KCTA 2008; MMAFK 2001; UNCTAD 1985; Yang et al. 2001) to use linear functions for $f_{i}$. For example, if a single container berth can provide service to $\mu_{B}$ TEU/year, and $\sigma_{i} \in(0,1)$ is a safety factor introduced to buffer against queueing delays, $f_{i}\left(n_{i}\right)=\left(\sigma_{i} \cdot \mu_{B}\right) \cdot n_{i} / K_{i}$, where $n_{i}$ is the number of berths, and $K_{i} \in(0,1]$ denotes the fraction $\lambda_{\text {tgt }}$ of that must be served by system $i$. Assuming that $n_{i}$ are integers, the model thus becomes

$$
\operatorname{Min} \sum_{i \in \Omega} c_{i} \cdot n_{i}
$$

subject to

$$
\lambda_{\text {tgt }} \leq \frac{\sigma_{i} \cdot \mu_{i} \cdot n_{i}}{K_{i}}, n_{i} \in \mathcal{Z}_{+}, \forall i \in \Omega
$$

The linearization of the $f_{i}$ renders the optimal solution $n_{i}^{*}$ trivial, 


$$
n_{i}^{*}=\left\lceil\frac{K_{i} \cdot \lambda_{t g t}}{\sigma_{i} \cdot \mu_{i}}\right\rceil, \forall i \in \Omega
$$

where $\lceil\cdot\rceil$ is the smallest integer greater or equal to its argument. If we relax our assumption on integer $n_{i}$, the optimal solution is $n_{i}^{R *}=K_{i} \cdot \lambda_{\text {tgt }} /\left(\sigma_{i} \cdot \mu_{i}\right), \forall i \in \Omega$. For the port systems we will consider $K_{i}=1, \forall i \in \Omega$.

Unless otherwise stated, we will use the solution $n_{i}^{R *}$; this will expose the thresholds we seek. When $n_{i}^{R *}$ is large, it will be relatively close to $n_{i}^{*}$ anyway.

Throughout, we will ignore quay to yard transportation because we assume it is the same for traditional operation and mobile harbor operation.

\subsubsection{Capacity calculation for port resources}

The "crane capacity based approach" (Yang et al. 2001) to calculate $\mu_{B}$ (the maximum sustained rate at which berths can process containers (TEU/unit time)) sets

$$
\mu_{\text {berth }}=n_{\text {crane }} \cdot \mu_{\text {crane }} \text {. }
$$

Here, $n_{\text {crane }}$ and $\mu_{\text {crane }}$ denote the mean number of quay cranes per berth and the maximum sustained rate at which a quay crane can execute lifts (TEU/unit time), respectively. Note that these values are intended to represent the maximum sustained throughput of the resource with uninterrupted operation. The safety factor $\sigma$ accounts for non-ideal operation.

We calculate the throughput capacity $\mu_{C T R}$ (TEU/unit time) of a container transport resource (CTR) (e.g. yard truck, feeder ship or mobile harbor) as in KCTA (2008). Let $D$ and $H_{C T R}$ denote the distance between two points and average number of TEU one transport resource can haul per round trip, respectively. Let $S_{\text {load }}^{C T R}, S_{\text {unload }}^{C T R}$ and $S_{\text {travel }}^{C T R}$ denote the speed of loading, unloading and travel, respectively, for the CTR. It is immediate that

$$
\mu_{C T R}=H_{C T R} /\left(\frac{H_{C T R}}{S_{\text {unload }}^{C T R}}+2 \cdot \frac{D}{S_{\text {travel }}^{C T R}}+\frac{H_{C T R}}{S_{\text {load }}^{C T R}}\right) .
$$

We use $\mu_{F}$ and $\mu_{M H}$ to denote this rate for a feeder ship and the mobile harbor, respectively. $H_{C T R}$ can account for multiple TEU capacity as well as dual cycle operation in which a CTR transports containers in both directions of its round trip. Such dual cycle may be more difficult for an $\mathrm{MH}$ than a yard truck since the stowage plan must be carefully considered.

\subsubsection{Safety coefficient for port resources}

The safety coefficient $\sigma$ mitigates queueing delays (via planning for less than $100 \%$ resource utilization) and accounts for non-ideal operation such as working days/ year, working hours/day, crane efficiency, rehandling containers, weather, interference between cranes, etc.

For a berth catering to 5000 TEU ships, MMAFK (2001) recommends a safety coefficient of $\sigma=0.216$. This is obtained by multiplying a resource efficiency 
coefficient (0.471) by target berth utilization (0.458). However, Yang et al. (2001) suggests the value of $\sigma=0.336$ since ship arrival times to ports are often carefully controlled and the ship (un)load rate has some flexibility (cranes can be rearranged). We will use $\sigma=0.336$. We assume the mobile harbor uses the same safety coefficient as a berth.

\subsection{Feasibility of the RORO only mobile harbor as a feeder ship}

We compare feeder ships versus mobile harbors (MHs) for the task of transporting containers between a hub and local port. Feeder ships and RORO only MHs have different travel and (un)load speeds.

Let $S_{\text {unload }}^{F}, S_{\text {load }}^{F}$ and $S_{\text {travel }}^{F}$ denote the rate at which containers can be unloaded from and loaded to a feeder ship and travel speed, respectively. Similarly define $S_{\text {unload }}^{M H}, S_{\text {load }}^{M H}$ and $S_{\text {travel }}^{M H}$. Assume $H_{M H}=H_{F}$. We use TEU/year as our unit of rate. Following the approach of Sect. 5.2, the number of feeder ships $n_{F}^{R *}$ and MHs $n_{M H}^{R *}$ to transport containers at a target rate $\lambda_{\text {tgt }}$ between two ports is $n_{F}^{R *}=\lambda_{\text {tgt }} /\left(\sigma_{i} \cdot \mu_{F}\right)$ and $n_{M H}^{R *}=\lambda_{t g t} /\left(\sigma_{i} \cdot \mu_{M H}\right)$, respectively. The rates $\mu_{F}$ and $\mu_{M H}$ are obtained from Eq. 2 and Table 9.

Let $C_{F}, C_{M H}, Q C C_{h u b}$ and $Q C C_{\text {local }}$ be the cost to own and operate one feeder ship/year, cost to own and operate one MH/year, quay crane cost/TEU at the hub port and quay crane cost/TEU at the local port. (Note that yearly 13\% operational costs in Sect. 4 include only berthing costs and not the per TEU QCC.) Assume the RORO MH will not pay this quay crane cost (It has its own crane).

The cost to provide $\lambda_{t g t}$ for feeder ship and $\mathrm{MH}$ service is $\lambda_{\text {tgt }}\left(Q C C_{h u b}+\right.$ $\left.Q C C_{\text {local }}\right)+C_{F} \cdot n_{F}^{R *}$ and $C_{M H} \cdot n_{M H}^{R *}$, respectively. Setting these equal and solving for $\mathrm{D}$ gives the distance between the ports at which both options have the same cost. Let $D_{B}$ denote this distance,

$$
D_{B}=\frac{H_{F}\left(\frac{C_{F}}{S_{\text {unload }}^{F}}-\frac{C_{M H}}{S_{\text {unload }}^{M H}}+0.5\left(Q C C_{\text {hub }}+Q C C_{\text {local }}\right) \cdot \sigma\right)}{\frac{C_{M H}}{S_{\text {travel }}^{M H}}-\frac{C_{F}}{S_{\text {travel }}^{F}}} .
$$

The MH is cheaper for distances $D \leq D_{B}$.

In addition to Tables 8 and 9, we use $Q C C_{h u b}=U S \$ 14.96 / T E U$ and $Q C C_{\text {local }}=$ US\$11.05/TEU (Kim et al. 2007). Despite the faster travel speed of the feeder ship, the MH RORO unloading is about twice as fast. Hence, for distances at or below $D_{B}=30.0 \mathrm{~km}$, the $\mathrm{MH}$ is a better option. If the $\mathrm{MH}$ yearly cost is reduced by $43 \%$ we have $D_{B}=100 \mathrm{~km}$ and the $\mathrm{MH}$ can service the same markets as typical short distance feeder ships with lower yearly cost.

\subsection{Replacing traditional land-based port berths}

\subsubsection{Replacing high cost berths}

Let us compare the costs of a traditional port (300 m length, $15 \mathrm{~m}$ depth, 4 quay cranes), an $\mathrm{MH}$ system (using a $40 \mathrm{~m}$ length, $5 \mathrm{~m}$ depth, no quay crane berth) and a 
Table 11 Required number of units and cost for expensive land property market

\begin{tabular}{|c|c|c|c|}
\hline & $\begin{array}{l}\text { Traditional } \\
\text { port }\end{array}$ & $\begin{array}{l}\text { Mobile harbor } \\
\text { (Crane and RORO) }\end{array}$ & Mid-stream \\
\hline Berths required & $\lambda_{\text {tgt }} /\left(\mu_{15 \mathrm{~m}} \cdot \sigma\right)$ & $\lambda_{\text {tgt }} /\left(\mu_{5 \mathrm{~m}}^{M H} \cdot \sigma\right)$ & $\lambda_{\text {tgt }} /\left(\mu_{5 \mathrm{~m}}^{\text {mid }} \cdot \sigma\right)$ \\
\hline MHs/lighters required & & $\lambda_{t g t} /\left(\mu_{M H} \cdot \sigma\right)$ & $\lambda_{\text {tgt }} /\left(\mu_{\text {mid }} \cdot \sigma\right)$ \\
\hline Total yearly cost (US\$/year) & $\frac{\lambda_{t g t}}{\mu_{15 \mathrm{~m}} \cdot \sigma} \cdot C_{15 \mathrm{~m}}$ & $\frac{\lambda_{t g t}}{\mu_{5 \mathrm{~m}}^{M H} \cdot \sigma} \cdot C_{5 \mathrm{~m}}^{M H}+\frac{\lambda_{t g t}}{\mu_{M H} \cdot \sigma} \cdot C_{M H}$ & $\frac{\lambda_{t g t}}{\mu_{5 \mathrm{~m}}^{m i d} \cdot \sigma} \cdot C_{5 \mathrm{~m}}^{m i d}+\frac{\lambda_{t g t}}{\mu_{m i d} \cdot \sigma} \cdot C_{m i d}$ \\
\hline $\begin{array}{l}\text { Calculated yearly cost } \\
(\mathrm{US} \$ /(\text { year } \cdot T E U))\end{array}$ & 60.46 & 63.80 & 37.07 \\
\hline
\end{tabular}

lighter system (using a $60 \mathrm{~m}$ length, $5 \mathrm{~m}$ depth, no quay crane berth). Assume a $25 \mathrm{~km}$ distance between the $5 \mathrm{~m}$ depth berths and the containership offshore (un)loading location. We calculate the container throughput rates $\mu_{M H}$ and $\mu_{m i d}$ of a single 250 TEU MH and single 250 TEU lighter, respectively. Let $\mu_{15 \mathrm{~m}}, \mu_{5 \mathrm{~m}}^{\mathrm{MH}}$ and $\mu_{5 \mathrm{~m}}^{\text {mid }}$ denote the container transfer rate per berth for the traditional, $\mathrm{MH}$ (crane and RORO) and midstream lighter berths, respectively. From Table 9 and Eq. 2 we obtain $\mu_{M H}=27.3 \cdot 24 \cdot 365=239,036, \mu_{\text {lighter }}=109,273, \mu_{15 \mathrm{~m}}=2,365,200$, $\mu_{5 \mathrm{~m}}^{M H}=1,051,200$ and $\mu_{5 \mathrm{~m}}^{m i d}=266,444$, (all in TEU/year) respectively.

Given this data, the resources required to provide a target TEU throughput rate $\lambda_{\text {tgt }}$ is given in Table 11. Let $C_{15 \mathrm{~m}}, C_{5 \mathrm{~m}}^{M H}, C_{M H}, C_{5 \mathrm{~m}}^{\text {mid }}$ and $C_{\text {mid }}$ denote yearly resource costs of a $300 \mathrm{~m}$ length and $15 \mathrm{~m}$ depth berth, $40 \mathrm{~m}$ lengh and $5 \mathrm{~m}$ depth berth for $\mathrm{MH}$, mobile harbor unit, $40 \mathrm{~m}$ lengh and $5 \mathrm{~m}$ depth berth for lighter and lighter, respectively. Evaluating, we obtain the yearly cost per TEU of target capacity; see Table 11. For the $\mathrm{MH}$ to be competitive with the traditional berth and midstream operators, it must reduce its yearly cost by $6 \%$ and $45 \%$, respectively. Production MHs may cost significantly less than the prototype. Further, so long as the cost is superior to the traditional berths, though the $\mathrm{MH}$ may not be as cost effective as midstream lighters, it can serve much larger ships (derrick cranes cannot serve ships above 4,000 TEU) and appeal to customers concerned about ship unloading time.

\subsubsection{Collection of small markets}

Assuming each port has the same throughput requirement, similar analysis shows that the MH solution promises to be more cost effective so long as the TEU traffic of each port is below 660,000 TEU/year.

\subsubsection{Inaccessible ports: Surabaya, Indonesia}

MHs can be used in mode M4 for inaccessible ports. Based on berth construction cost, channel expansion cost, dredging cost and throughput estimates from JICA (2007), a yearly cost decrease of $46 \%$ will enable the $\mathrm{MH}$ to be competitive. 


\subsection{Direct ship-to-ship resource}

Let $\tau \in(0,1)$ denote the fraction of total port throughput that can be STS transshipped. To provide this STS service with MHs will cost $\left(\tau \cdot \lambda_{t g t} \cdot C_{M H C}\right) /\left(\mu_{M H} \cdot \sigma\right)$. This $C_{M H C} /\left(\mu_{M H} \cdot \sigma\right)$ per TEU $\cdot$ year should be compared to US\$ 50 and US\$ 21.725 for traditional CHC and STS CHC (see Sect. 2.2.3), respectively.

\subsection{Mobile harbor as a supplementary resource in a traditional port}

Mobile harbor units can serve as a supplementary resource either as a variety of offshore berth or to conduct double sided (un)loading at a land berth. For example, if a port cannot increase existing capacity with new berths, mobile harbor units may provide extra capacity at less cost than a new berth.

\subsection{Sensitivity analysis}

\subsubsection{Sensitivity analysis for mobile harbor scale}

Here we investigate the feasibility of various sizes of $\mathrm{MH}$ to provide modes M1, M2 and M4. Ideally, we would like to study across all possible $\mathrm{MH}$ capacities and identify an optimal TEU carrying capacity. This is complicated by the non-linear (and unknown to us) relationship between parameters such as travel speed, (un)loading speed, cost and TEU carrying capacity. As detailed designs have been created for three sizes of mobile harbor: 250, 600 and 1,200 TEU, we focus on these. The cost and operation data is given in Tables 8 and 9.

Aside from the container carrying capacity, the key differences are the number of on-board cranes ( 1 for the 250 and 600 TEU MHs and 2 for the 1,200 TEU MHs) and the size of the berth required (40, 60 and $80 \mathrm{~m}$ for the 250, 600 and 1,200 TEU MHs, respectively) [MH report 2009]. Obviously costs are different.

Using the same approach as for the 250 TEU analysis, we obtain the break even distance for the various sizes of RORO only $\mathrm{MH}$ when used as a feeder ship as $30.03 \mathrm{~km}, 49.57 \mathrm{~km}$ and $97.94 \mathrm{~km}$ for the 250 TEU, 600 TEU and 1,200 TEU MHs, respectively. For smaller distances, the RORO MH is more economical than a regular feeder ship with the same capacity. The breakeven distance increases as the capacity of the transfer units increase.

Similarly, for mode M2 (in Hong Kong), the crane and RORO MHs cost US $\$ 63.8,81.47$ and $70.41 /($ TEU $\cdot$ year $)$ for the 250, 600 and 1200 TEU capacity crane and RORO MHs, respectively. The 250 TEU capacity is the best (travel distance is small for this case). It has $6 \%$ greater cost than the traditional port.

Using the same approach as previously, we study the yearly cost per TEU of using the larger $\mathrm{MH}$ units in Surabaya, Indonesia. The $\mathrm{MH}$ solutions cost US\$76.79, 91.40 and 78.08/(TEU $\cdot$ year $)$ for the 250, 600 and 1200 TEU capacity cases, respectively. The $250 \mathrm{TEU}$ mode is the best of the three. 


\subsubsection{Sensitivity analysis for Hong Kong market}

In this section, we focus on the most promising application and investigate the sensitivity of the crane and RORO MH's yearly resource cost to purchase cost, RORO speed, crane speed and travel speed in the Hong Kong market. The yearly cost/TEU for MHs in Hong Kong is calculated as

$$
\frac{1}{\mu_{5 \mathrm{~m}}^{M H} \cdot \sigma} \cdot C_{5 \mathrm{~m}}^{M H}+\frac{1}{\mu_{M H} \cdot \sigma} \cdot C_{M H} .
$$

where $\mu_{M H}$ is calculated using Eq. 2; other variables were introduced in Sect. 5.4.1. We use the popular spider diagram (David 1997; Eschenbach 1992; Ma et al. 2004) to depict the results; see Fig. 14. It shows the elasticity of objective function value to changing input parameters. For reference, the estimated yearly cost of traditional and mid stream operations, US\$60.46/(TEU $\cdot$ year) and $U S \$ 37.07 /(T E U \cdot$ year $)$, respectively, are depicted as constant lines in Fig. 14. The x-axis represents the $\%$ change in a given parameter from our nominal value. The y-axis gives the resulting US\$ cost per $(T E U \cdot$ year $)$ of the crane and RORO 250 TEU MH solution with all other parameters fixed. The $\mathrm{MH}$ will be more favorable than a traditional port and mid stream if it reduces its purchase cost by $6 \%$ and $45 \%$, respectively.

Alternatively, the MH could increase its RORO speed by $22 \%$ or travel speed by $18 \%$ or crane speed by $16 \%$ (holding other values fixed) to be more competitive than the traditional port. Lower bounds obtained by improving performance parameters are US\$45.47,US\$42.12 and $U S \$ 40.01 /(T E U \cdot$ year $)$ for RORO

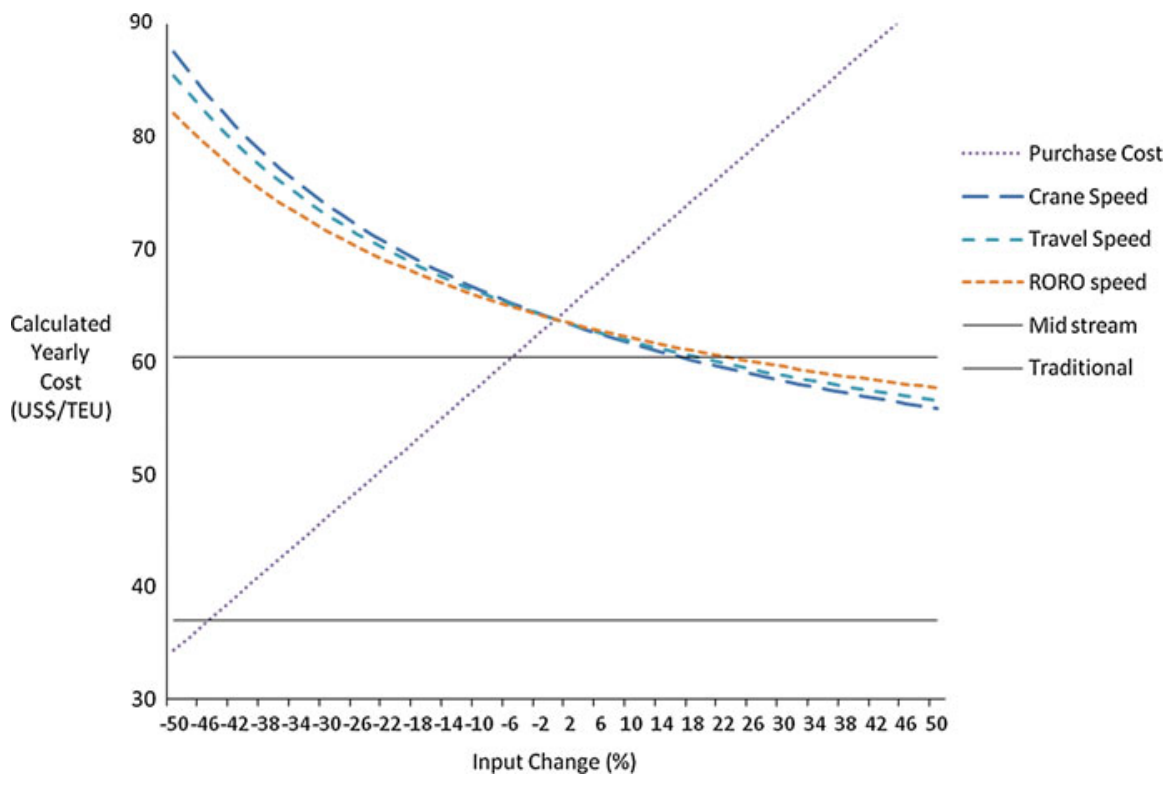

Fig. 14 Result of sensitivity analysis for the Hong Kong market 
speed, travel speed and crane speed, respectively. Therefore, it cannot be cheaper than mid stream operators by changing these values alone.

\section{Concluding remarks}

As demand for container transport continues to increase, it behooves us to investigate nontraditional port service concepts such as offshore operation. To that end, we developed a classification for offshore operation concepts and operational modes. We used the classification to conduct a review of existing offshore service concepts. To our knowledge, it is both complete and the first attempt to organize and classify such concepts. Advantages, disadvantages and the container handling chain were discussed for each.

We next turned our attention to the study of one of these concepts, the mobile harbor $(\mathrm{MH})$. There, our goal was to investigate the economic feasibility of the idea across a variety of operational modes and answer the question: "Should such a concept be implemented?" We employed industry data and time honored throughput based calculations to provide estimates of economic feasibility. The 250 TEU crane and RORO MH cost was within $6 \%$ of the cost of traditional ports in Hong Kong. For a collection of small ports, each with 660,000 TEU/year demand, the 250 TEU crane and RORO MH was viable. Other operational modes were not so favorable. Sensitivity analysis in the Hong Kong market revealed that improvements in numerous parameters would improve competitiveness of the $\mathrm{MH}$.

Offshore operation concepts may have promise as the container traffic of the future continues to increase. Although the $\mathrm{MH}$ only proved nearly competitive for limited applications, there are other considerations. We did not include the basic advantages of offshore structures, nor did we quantify the MHs flexibility to provide all six modes of operation.

Future work could develop detailed analytic or simulation models to give more accurate values for the number of resources required. Accurate cost or parameter estimates would be most helpful. In addition, the identification of other modes of operation for offshore structures could lead to other economically feasible modes of operation.

Acknowledgments The authors wish to thank the anonymous reviewers, journal editors and special issue editors. The paper is much improved for their insightful suggestions. The work reported here has been supported in part by the Korean Ministry of Knowledge Economy Grant 10036222 and 10036229.

Open Access This article is distributed under the terms of the Creative Commons Attribution Noncommercial License which permits any noncommercial use, distribution, and reproduction in any medium, provided the original author(s) and source are credited.

\section{References}

Abdel-Maksoud M, Wichner W (2008) Offshore container transfer station as part of a logistics system. Publication number: PCT/EP2007/001474, publication date: 28 Aug 2008 
Baird AJ, Jeon IS (1999) Trend of mega container ship and countermeasure. Korean J Port 71:64-82. Title translated from the Korean. http://academic.naver.com/view.nhn?doc_id=10854067\&dir_ $\mathrm{id}=10204 \&$ field=0\&sort=0\&query=\%EB $\% 8 \mathrm{C} \% 80 \% \mathrm{ED} \% 98 \% 95 \% \mathrm{ED} \% 99 \% 94 \% \mathrm{EC} \% 99 \% 80 \&$ page $=1$. Accessed 16 Apr 2011

Cavotec Specimas (2011) Product catalogue-automated mooring systems. http://www.cavotec. com/static/upload/media/Automated\%20Mooring\%20Systems\%20catalogue.pdf. Accessed 12 Jan 2011

Chae JW, Park WS, Yi JH, Jeong G (2007) A floating mobile quay for a very large container ship. Proceedings of the 4th international conference on Asian and Pacific Coasts, Nanjing, 21-24 Sept 2007

David DJ (1997) Pannell sensitivity analysis of normative economic models: theoretical framework and practical strategies. Agric Econ 16:139-152

Drewry Shipping Consultants Ltd (2007a) Annual review of global container terminal operators 2007. http://www.drewry.co.uk/publications/view_publication.php?id=221. Accessed 16 Apr 2011

Drewry Shipping Consultants Ltd (2007b) Container market review and forecast 2006/2007. http://www.drewry.co.uk/publications/view_publication.php?id=214. Accessed 16 Apr 2011

Eschenbach TG (1992) Spider plots versus tornado diagrams for sensitivity analysis. Interfaces 22:40-46

Fung KF (2001) Competition between the ports of Hong Kong and Singapore: a structural vector error correction model to forecast the demand for container handling services. Marit Policy Manage 28(1):3-22

Gottwald Port Technology Website for Floating Cranes (2010) Gottwald floating cranes-innovation on the water. http://www.gottwald.com/gottwald/site/gottwald/en/products/harbour-cranes/floating cranes.html. Accessed 27 Dec 2010

Han SH, Kim IJ (2009) Container ship to container ship trans-shipment system. South Korean patent application, filing number: 1020090082786, filing date: 3 Sept 2009

Han SH, Kim IJ, Jung TY (2009) Floating terminal for trans shipment of container. South Korean patent application, filing number: 1020090087057, filing date: 15 Sept 2009

Han SH, Lee JH (2009) Container docking system, container crane, and container docking method, container crane and container docking method. South Korean patent application, filing number: 1020090082529, filing date: 2 Sept 2009

Hong Kong Mid-Stream Operators Association (HKMOA) (2009) http://www.hkmoa.com/Development. aspx?lang=E. Accessed 9 Sept 2009

Huang Y, Liang C, Yang Y (2009) The optimum route problem by genetic algorithm for loading/ unloading of yard crane. Comput Ind Eng 56(3):993-1001

Hydrospex (2011) Skidding system. http://www.hydrospex.nl/new/productmain.asp?cat=3. Accessed 13 Jan 2011

Im SH (2008) Europe canal bench marking business trip report. Korea Institute of Construction \& Transportation Technology Evaluation and Planning: 4. Title translated from the Korean. https://www.kictep.re.kr/app/notice/notice_01_view.jsp?_idx=1770\&_pid=global_report\&_div=\&_ mid=M050700\&skey=\&stype=\&pnum=1. Accessed 16 Apr 2011

Japan International Cooperation Agency (JICA) (2007) The study for the development of the greater Surabaya metropolitan ports in the Reublic of Indonesia. Technical report, sector: transportation

Jeong TG, Kim SW, Lee YS (2010) Feasibility analysis of ship-to-ship stabilized mooring system applicable to the mobile harbor. Proceeding of MARTECH 2010 9th international conference and exhibition, Singapore, 27 Apr-2 May 2011

Jung H, Kwak BM (2009) Balance keeping crane and vessel with the crane. South Korean patent application, filing number: 10-2009-0074380, filing date: 12 Aug 2009

Kim BK (2009a) Mobile harbor system and method for simultaneous performing of container loading and unloading. South Korean patent application, filing number 1020090074794, filing date: 13 August 2009

Kim JH, Kim HJ, Lee TE, Cho KJ, Lee SH (2010) High speed quayside container handling systems based on mobile harbor. Proceedings of the 2010 Korea Industrial Engineering/Management Science conference, Jeju Island, 3-4 June 2010

Kim SH, Kim UH, Hong YS, Ju HJ, Kim J, Kwak YG, Kwak BM (2009) Auto landing, location, locking device for spreader of crane and method thereof. South Korean patent application, filing number: 1020090074305, filing date: 12 Aug 2009

Kim WS, Choi SH, Ha TY (2007) A Study on an energy cost-saving plan for container terminals. Korea Maritime Institute (KMI) technical report. Title translated from the Korean. http://academic. 
naver.com/view.nhn?doc_id=38127791\&dir_id=102\&field=0\&sort=0\&query=\%EC\%BB\%A8\%ED\% 85\%8C\%EC\%9D\%B4\%EB\%84\%88\%20\%EC\%A0\%88\%EA\%B0\%90\&page=1. Accessed 16 Apr 2011

Kim YB (2009b) Motion response and mooring analysis of mobile harbors moored in side-by-side. J Ocean Eng Technol 23(6):53-60

Korea Container Terminal Authority (KCTA) (2008) Third phase berth construction report of Gwang Yang terminal in Korea. Title translated from Korean. http://academic.naver.com/view.nhn? doc_id=18287378\&dir_id=1\&field=0\&sort=0\&query=\%EA \%B4\%91\%EC\%96\%91\%ED\%95\%AD $\% 201 \%$ EC\%B0\%A8\&page=1. Accessed 13 Jan 2011

Kwak BM, Oh JH (2009) Balance keeping crane and vessel with the crane. South Korean patent application, filing number: 1020090070799, filing date: 31 July 2009

Lee JH, Yoon SJ, Jung H, Lee PS (2010) The conceptual design of semi-submersible type mobile harbor using axiomatic design principles. Proceedings of the 2010 Korean CAD/CAM conference, Pyeongchang, 27-19 Jan 2010, pp 189-203

Lee PS, Jung H, Lee DY, Kim SI (2009a) Docking system for a ship and docking method using the same. South Korean patent application, filing number: 1020090074208, filing date: 12 Aug 2009

Lee PS, Jung H, Yoon SJ, Lee YG, Nam CH, Woo HG, Jang CW, Choi WY (2009b) Semi-submersible mobile harbor and method for transporting containers using the same. South Korean patent application, filing number 1020090045697, filing date: 25 May 2009

Lewis PF (2003) New Orleans: The making of an urban landscape. University of Virginia Press, Charlottesville

Liang C, Huang Y, Yang Y (2009) A quay crane dynamic scheduling problem by hybrid evolutionary algorithm for berth allocation planning. Comput Ind Eng 56(3):1021-1028

Lindstad H, Uthaug E (2003) Innovative technology: Ro-Ro vessel, terminal, and barge design that will improve the cost position and lead-time for the logistic chain. IMDC 03 conference, Athens, 3-5 June 2003

Ma F, Zhang H, Bockstedte A, Foliente GC, Paevere P (2004) Parameter analysis of the differential model of hysteresis. J Appl Mech 71:342-349

March J (2005) Integriertes terminal-schiff-system (ITSS) für übergro $\beta$ e Containerschiffe. German patent no. DE10202384A1, granted date: 16 June 2005

Marco RO (2007) Logistical and economic aspects of the floating container crane within a network terminal. MSc thesis, TU Delft

Mobile Harbor Business Team (MHBT) (2011) An introduction material about the mobile harbor project. http://www.mobileharbor.or.kr/index.html $\rightarrow$ English $\rightarrow$ Public Relation $\rightarrow$ Brochure. Accessed 13 Jan 2011

Minchin D (2006) The transport and the spread of living aquatic species. Environ Pollut 10:77-97

Ministry of Maritime Affairs and Fisheries of Korea (MMAFK) (2001) Modified port development plan. Title translated from Korean. http://academic.naver.com/view.nhn?doc_id=18075302\&dir_id=0 $\&$ field $=0 \&$ sort $=0 \&$ query $=\% \mathrm{EC} \% 88 \% 98 \% \mathrm{EC} \% \mathrm{~A} 0 \% 95 \% 20 \% \mathrm{ED} \% 95 \% \mathrm{AD} \% \mathrm{~EB} \% \mathrm{~A} 7 \% 8 \mathrm{C} \% 20 \% \mathrm{EA}$ $\%$ B3\%84\%ED\%9A\%8D\&page=1. Accessed 13 Jan 2011

Morrison JR, Lee TS (2009) Decoupling (un)loading operations from the land-sea interface in port service: the mobile floating port concept. Proceedings of the 5th international conference on axiomatic design, Lisbon, 25-27 March 2009, pp 57-63

Morrison JR, Lee TS, Kim MS, Kim JH, Shin KH and Sung IK (2009a) Hybrid mobile floating port. South Korean patent application, filing number 1020090096907, filing date: 3 Dec 2008

Morrison JR, Lee TS, Kim MS, Kim JH, Shin KH and Sung IK (2009b) Hybrid mobile floating port. South Korean patent application, filing number 1020080131310, filing date: 22 Dec 2008

Pierson-Moskowitz Sea Spectrum (2011) Values are worst case forecasts for open water in vicinity of referenced point. http://www.syqwestinc.com/support/Sea\%20State\%20Table.htm. Accessed 8 Apr 2011

Sanyal S (2002) LASHed, but not out. The Hindu Business Line, Monday, 23 Sept 2002. http://www. thehindubusinessline.com/2002/09/23/stories/2002092300590600.htm. Accessed 20 Dec 2010

Shipping and Port Internet Data Center (SPIDC) (2011) Container transportation statistics. http://www. spidc.go.kr. Accessed 16 Apr 2011

Shin HK, Shin JW, Kim MS, Jung WJ (2009) Docking system of ship. South Korean patent application, filing number: 1020090093030 , filing date: 30 Sept 2009

Suh NP (2008) Mobile harbor to improve ocean transportation system and transportation method using the same. Korean patent no. 100895604, granted date: 23 Apr 2008

Suh NP (2009) Mobile harbor using vibration isolation for positioning platform. South Korean patent application, filing number: 1020090043735, filing date: 19 May 2009 
Sullivan WG, Wicks EM, Luxhoj JT (2003) Engineering economy. 12e, International edition. Prentice Hall, New Jersey

Talley WK (2006) An economic theory of the port. In: Cullinane K, Talley KW (eds) Port economics: research in transportation economics 16. Elsevier, Amsterdam, pp 43-65

Tongzon J (2001) Efficiency measurement of selected Australian and other international ports using data envelopment analysis. Transp Res Part A Policy Practice 35(2):107-122

United Nations Conference on Trade and Development (UNCTAD) (1985) Port development: a handbook for planners in developing countries. United Nations. http://www.rO.unctad.org/ttl/ docs-un/td-b-c4-175-rev-1/TD.B.C.4.175.REV.1.PDF. Accessed 13 Jan 2011

Vis IFA, Carlo HJ (2010) Sequencing two cooperating automated stacking cranes in a container terminal. Transp Sci. doi:10.1287/trsc. 1090.0298

Wright International Webpage for Cost of a 660TEU Feeder Ship (2010) http://www.wright-international. com/wil1462-660teucontainerfeedership.php. Accessed 29 Dec 2010

Yang CH (2003) Research of future container terminal development direction by the use of floating structure. Korea Maritime Institute (KMI) technical report. Title translated from the Korean. http://academic.naver.com/view.nhn?doc_id=38123426\&dir_id=10204\&field=0\&sort=0\&query $=\%$ EB\%B6\%80\%EC\%9C\%A0\%EA\%B5\%AC\%EC\%A1\%B0\%EB\%AC\%BC\&page=1. Accessed 16 Apr 2011

Yang CH, Kim CG, Bae JW (2001) Research on the method to estimate container terminal capacity. Korea Maritime Institute (KMI) technical report. Title translated from the Korean. http://academic. naver.com/view.nhn?doc_id=38120844\&dir_id=1\&field=0\&sort=0\&query $=\% \mathrm{EC} \% 8 \mathrm{~B} \% \mathrm{~A} 0 \% \mathrm{EC} \%$ 84\%9D\%EC\%B2\%98\%EB\%A6\%AC\&page=1. Accessed 16 Apr 2011

Yang CH, Kim CG, Choi JH, Choi SH, Choi YS, Lee JH (2002) Research on next generation port unloading system technology development to address very large container ship. Korea Maritime Institute (KMI) technical report. Title translated from the Korean. http://academic.naver.com/view. nhn?doc_id=38120876\&dir_id=10204\&field=0\&sort=0\&query $=\% \mathrm{EC} \% \mathrm{~B} 0 \% \mathrm{~A} 8 \% \mathrm{EC} \% 84 \% \mathrm{~B} 8 \% \mathrm{~EB} \%$ 8C\%80\%20\%ED\%95\%AD\%EB\%A7\%8C\%20\&page=1. Accessed 16 Apr 2011

Yang DY (2009) Vessel for cargo handling at both side of a container ship. South Korean patent application, filing number: 1020090066613, filing date: 22 July 2009

Yang DY, Im TW, Son Y (2009a) Loading and unloading apparatus of a mobile harbor for continuous sea transport and method thereeof. South Korean patent application, filing number: 1020090085443, filing date: 10 Sept 2009

Yang DY, Lee PS, Jung H, Kwak BM, Suh NP (2009b) Loading and unloading equipment of a mobile harbor and method thereof. South Korean patent application, filing number: 1020090045667, filing date: 25 May 2009

Yoon YS (2008) Mobile harbor. South Korean patent application, filing number: 1020080090655, filing date: 16 Sept 2008

Zhao QA (2006) Talking about Yangsan port from captain's viewpoint. Navig China 1:20-25

\section{Author Biographies}

Jonghoe Kim received B.S. and M.S. degrees in Industrial and Systems Engineering from KAIST (Korea Advanced Institute of Science and Technology), South Korea. He is currently a Ph.D. candidate in the Department of Industrial and Systems Engineering, KAIST, South Korea. His research interests include system design, service science and revenue management.

James R. Morrison received one B.S. degree in electrical engineering and a second B.S. degree in mathematics from the University of Maryland, College Park, and the M.S. and Ph.D. degrees in electrical and computer engineering from the University of Illinois at Urbana-Champaign, Urbana, in 1997 and 2000, respectively. He was with the Fab Operations Engineering Department at the IBM Corporation from 2000 to 2005. He is currently an Associate Professor in the Department of Industrial and Systems Engineering, KAIST (Korea Advanced Institute of Science and Technology), South Korea. His research interests include semiconductor wafer fabrication, system design, queueing networks and stochastic control. Prof. Morrison became a Co-Chair of the IEEE Robotics and Automation Society Technical Committee on Semiconductor Manufacturing Automation in September 2008. 